1994

\title{
Constitutional Law and International Law in the United States of America
}

Lung-chu Chen

New York Law School, lungchu.chen@nyls.edu

Follow this and additional works at: http://digitalcommons.nyls.edu/fac_articles_chapters

Part of the Constitutional Law Commons, International Law Commons, and the President/ Executive Department Commons

\section{Recommended Citation}

42 American Journal of Comparative Law 453-516 (1994)

This Article is brought to you for free and open access by the Faculty Scholarship at DigitalCommons@NYLS. It has been accepted for inclusion in Articles \& Chapters by an authorized administrator of DigitalCommons@NYLS. 
TOPIC IV.A

\section{LUNG-CHU CHEN}

\section{Constitutional Law and International Law in the United States of America}

\section{INTRODUCTION}

We the People of the United States, in order to form a more perfect Union, establish Justice, insure domestic Tranquility, provide for the common defence, promote the general Welfare, and secure the Blessings of Liberty to ourselves and our Posterity, do ordain and establish this Constitution for the United States of America. ${ }^{1}$

With these words the founders of the United States government began the first written constitution, and thereby established the first constitutional democracy in the modern era. At the time of its adoption, the United States Constitution represented a radical idea: that people could govern themselves through a system of written laws, not by the edicts of some "divine" monarch. The more than two-hundredyear history of this remarkable document is a testament to the durability of that idea. The American constitutional system has survived civil war, economic upheaval, and social turmoil from within, and weathered the challenges and pressures, and even the threats to its very survival, from abroad. It remains as vibrant and vital today as in the days of its creation, demonstrating a unique capacity to adapt to the changing conditions and the evolving demands and expectations of modern life. While unique at its inception, the American constitutional system has served as a model for numerous nations around the world, a further testament to the enduring genius of its founders.

The original Constitution, as adopted by the several states in 1789 , consisted of only seven articles. Over the years, twenty-seven amendments have been added. The Constitution is, however, greater

LuNG-Chu Chen is Professor of Law, The New York Law School and Research Affiliate in Law, Yale Law School. LL.B., National Taiwan University, 1958; LL.M., Northwestern University, 1961; LL.M., 1962 and J.S.D., 1964, Yale University.

The author gratefully acknowledges the valuable assistance of James $\mathrm{T}$. McClymonds in the preparation of this article. The author also gratefully acknowledges the assistance of Susan Henner, Leslie Kanocz, and Joel McHugh.

1. U.S. Const. pmbl. 
than the sum of its written parts. It is a dynamic and continuous process of communication, practice and decision through which the citizens of the United States establish and maintain the basic features of authoritative decision that govern their society. The Constitution is not a process locked into any one given time or era. Through the exercise of collective decision-making outlined by the Constitution, the citizens of the United States have ensured that the values enshrined in the Constitution reflect not only the vision and goals of those who originally drafted the document, but also the demands and expectations of succeeding generations.

The strength of the American system of government derives from several fundamental principles that are woven directly into the fabric of the Constitution itself, which will be discussed in more detail later. First, the American system is a federalism, where power is allocated throughout a vertical structure of local, state and national governments. ${ }^{2}$ Second, power is also allocated horizontally within each level, in a system commonly referred to as separation of powers. ${ }^{3} \mathrm{Fi}$ nally, the basic human rights of the individual are protected against intrusion and overreaching by the government through the very structure of government itself as well as the interpretation and application of a Bill of Rights. ${ }^{4}$ The result is a dynamic process through which the people of the United States pursue their common interests and secure "the Blessings of Liberty" for themselves and their posterity. ${ }^{5}$

The constitutional process of the United States operates in the context of a world community of ever growing interdependence. An important outcome of the continuous process of authoritative decision in the United States is the shaping and sharing of community policies regarding America's role in the global community and its conduct in foreign affairs. The transparency of the American constitutional system of governance allows individuals at all levels of American society

2. See infra Sec. II.A.

3. See infra Sec. III.A.

4. The first 10 amendments to the U.S. Constitution, commonly referred to as the Bill of Rights, explicitly provide for limitations on federal power vis-a-vis the individual, including freedom of speech, the press, and assembly, the right to bear arms, freedom from unreasonable search and seizure, the right to a jury trial, and the guarantee of due process of law. See U.S. Const. amends. 1, 2, 4, 5, 6, 7. The Fourteenth Amendment, adopted after the Civil War, incorporates many of these rights and applies them to the states. See U.S. Const. amend. 14. The Fourteenth Amendment also guarantees the equal protection of the laws. See id. Like the Constitution itself, the Bill of Rights is not a static set of guarantees. It is a dynamic process of continuing communication, practice and decision through which generations of Americans have secured freedom from the possibility of oppressive government and majoritarian tyranny.

5. For a more complete discussion of the dynamic nature of the United States Constitution and the Bill of Rights, see generally Chen, "Institutions Specialized to the Protection of Human Rights in the United States," 1 N.Y.L. Sch. Hum. Rts. Ann. 3 (1983). 
to contribute to the establishment and application of inclusive world order decisions. ${ }^{6}$

Equally important is the effect of world order decisions on the national law of the United States. Two theories have emerged from the traditional debate over the nature of the relationship between international law and national law: dualist theory and monist theory. Under dualist theory, international law and national law are two separate and distinct bodies of law. Each system has its own subjects, structures and processes of authority, and content. The typical process by which international law becomes national (or municipal) law, under dualist theory, is by "adoption," "incorporation," "transformation," and so on.

Monist theory, on the other hand, holds that there is a unitary legal system. International law and national law each have the same subjects, sources, and content, generally with international law supreme over national law. Norms, under the monist theory, fall within levels or hierarchies, with international norms generally at the top of the pyramid.

Common to both systems is a focus on norms or "rules." The problem with both theories, and the rules-based approach in general, is that they fail to adequately account for and describe the entire process of authoritative decision-making. ${ }^{7}$ This is particularly true in the changing context of global and national interdependence. In a world of global communications, an increasingly interdependent economy, transboundary environmental impacts, and modern weapons and techniques of war, people from opposite ends of the globe have a real and dramatic effect on each other. Decisions made locally can have inclusive effects, with impacts reaching the national, regional, and international levels. Consequently, just as decision processes within the United States have effects on the international community, decision processes in other nations and in intergovernmental organizations at the regional and international levels impact and affect conditions, and ultimately the law, in the United States. ${ }^{8}$

The dynamics of this interpenetrating process of decision-making means that at times, there will be conflicts between national and international law. When such conflicts arise, it is imperative that international law should prevail. The supremacy of international law

6. See infra Sec. VII.

7. For a more detailed criticism of the rule-centered approach to international law, and a description of the New Haven School policy-oriented approach, see Lungchu Chen, An Introduction to Contemporary International Law: A Policy-Oriented Perspective 3.22 (1989).

8. See McDougal, "The Impact of International Law Upon National Law: A Policy-Oriented Perspective," in, Myres S. McDougal \& W. Michael Reisman, International Law Essays: A Supplement to International Law in Contemporary Perspective 437 (1981). 
is essential to the maintenance of world order and ensures that the inclusive policies of the world community are put into effective practice.

The supremacy of international law is generally recognized within the constitutional system of the United States. The Constitution itself provides that treaties are the supreme law of the land. ${ }^{9}$ Through practice and judicial interpretation, other types of international agreements have been held to have the same status as treaties as supreme law. International customary law, although not supreme law in the sense of treaties and international agreements, is considered to be part of the federal common law, applicable by both state and federal judges. Through each of these modalities, the inclusive policies and world order goals of the international community become effective law in the United States binding on the nation itself as a member of the community of nations, as well as upon individuals within the United States where applicable.

This report will explore the constitutional processes that govern the establishment and conduct of American foreign affairs. Within this broad outline, there are several areas of special concern. First, the report will describe the vertical allocation of powers that govern foreign affairs - the vertical allocation of powers refers to the relationship between the federal government and the several state governments that make up the United States, and the division of responsibility between them.

Second, the horizontal allocation of power - the relationship between the several branches of the federal government - will be explored. Because foreign affairs powers are shared among the executive, legislative and judicial branches of government, issues regarding the competency of the branches to act in foreign affairs, questions regarding separation of powers, and issues of checks and balances continually arise. In particular, the President's role as sole representative of the United States in foreign affairs, the Congress's shared responsibility for the formulation of American foreign policy, and the judiciary's role as final arbiter and interpreter of international law will be discussed.

Finally, a theme running throughout this report is the role of the citizen, both in an individual capacity and as a member of groups, in the external affairs of the United States. By focusing on all participants, the dynamics and full complexity of the American foreign affairs decision making process will be revealed.

9. See U.S. Const. art. VI. 


\section{The Vertical Allocation of Powers}

\section{A. The Federal System in Action in the United States}

A central feature of the United States constitutional system is that it is a federalism in which power is distributed vertically among overlapping governments. At the top of the structure is the federal, or national, government encompassing the entire territorial United States. Below the federal government are the fifty states, each with its own state government and territory. Each state is then further divided into local subdivisions.

To better understand how American federalism operates, it is helpful to examine the history behind the adoption of the Constitution. In 1781, at the close of the American War of Independence, the thirteen original colonies formed a loose confederation under the Articles of Confederation. The purpose of the Articles of Confederation was to ensure some unity of the states in dealing with common foreign and domestic problems: but the overriding understanding was that the states would remain sovereign. The Articles provided for a single organ of the national government, a Congress, with very limited powers: the sole and exclusive right and power to determine issues of peace and war; the authority to resolve disputes between the states; the power to regulate the value and alloy of coin; the authority to deal with the native American Indian tribes; the power to establish or regulate post offices; and the power to appoint naval and other officers in federal service. The key powers lacking in the federal government under the Articles were the power to tax and the power to regulate commerce. Moreover, there was no executive or general judicial power at the national level.

Due to the very limited powers of the federal government established under the Articles of Confederation, the thirteen states soon encountered a variety of problems. Congress was unable to raise the revenues necessary for the functioning of the national government and for the payment of the national debt incurred during the War of Independence, and the states could not be counted upon to fulfill their obligations. Without a national executive power, the federal government found it difficult to conduct both domestic and foreign affairs. Finally, interstate rivalries and jealousies led to retaliatory trade wars among the states, inhibiting the free flow of interstate commerce.

By 1786, it had become clear that amendments were needed to remedy the problems facing the thirteen states. A convention was held in Philadelphia to amend the Articles of Confederation. How- 
ever, the delegates went beyond their mandate, and negotiated a completely new document, the Constitution. ${ }^{10}$

The new Constitution retained some of the features of the Articles of Confederation. Under the Constitution, the states are still autonomous entities with the full police powers generally associated with sovereign states. The autonomy of the states is reflected in the Tenth Amendment, which provides: "The powers not delegated to the United States by the Constitution, nor prohibited by it to the States, are reserved to the States respectively, or to the people."11 The sovereign immunity of the states is reflected in the Eleventh Amendment, which provides: "The Judicial power of the United States shall not be construed to extend to any suit in law or equity, commenced or prosecuted against one of the United States by Citizens of another State, or by Citizens or Subjects of any Foreign State." ${ }^{12}$

The federal government provided for in the Constitution, as under the Articles of Confederation, is still a government of limited powers, capable of exercising only those powers ceded to it by the states and enumerated in the Constitution. ${ }^{13}$ However, the Constitution provided the federal government several key powers that it lacked under the Articles of Confederation: the power to lay and collect taxes; the power to regulate commerce with foreign nations, among the several states, and with the native American Indian tribes; the power to make all laws necessary and proper to exercise its enumerated powers; and several key foreign affairs powers.

The American federal system - several autonomous states joined together under a national government of limited powers was designed to promote several important values. It was intended that the states retain an important function within the constitutional framework. Most of the important functions of government would be conducted at the state level; the federal government would only be necessary during times of war. ${ }^{14}$ Federalism was thought to encourage experimentation, where each state would be free to develop and implement new solutions to problems without risk to the entire nation, and to foster efficiency by allowing states to tailor solutions to local problems. Moreover, federalism was thought to promote individual choice and democracy by allowing citizens more direct input into matters of local concern.

10. For a discussion of the history of the Constitution, see Geoffrey R. Stone et al., Constitutional Law 1-21 (2d ed. 1991). For a more complete study, see Max Farrand, The Framing of the Constitution of the United States (13th ptg. 1978).

11. U.S. Const. amend. 10 (the 10th Amendment was adopted as part of the Bill of Rights in 1791).

12. Id. amend. 11 (the 11 th Amendment was adopted in 1798).

13. See id. art. I, sec. 8.

14. See The Federalist Nos. 45 and 46 (Madison). 
The framers' vision of a national government which would be necessary only during times of war proved to be unrealistic. As discussed below, with the expansion of the commerce power, the federal government has grown both in power and in importance. ${ }^{15}$ Nevertheless, federalism still thrives even today, and the essential tension between federal and state power remains a vital feature of the American constitutional system, as illustrated by the argument over "States Rights" and the present trend in state courts to interpret and apply state constitutions as separate and distinct from the federal Constitution.

\section{B. The Foreign Affairs Power of the Federal Government}

One area in which the federal government is considered to have full plenary powers, exclusive of the States, is in the area of foreign affairs. Nothing in the Constitution expressly provides for the exclusive federal foreign affairs power. Nevertheless, it is generally accepted that the foreign affairs powers are exclusively federal, either expressly, as in the treaty power, or inherently, as in the power to declare war. States generally lack competence to act in the arena of foreign relations.

The rationale for exclusive federal foreign affairs power was elaborated by the United States Supreme Court in United States $v$. Curtiss-Wright Export Corp. ${ }^{16}$ In that case, the Court ruled on the validity of a congressional joint resolution delegating to the president the power to declare certain arms sales illegal. In upholding the resolution, the Court held that the foreign affairs powers of the United States are exclusively vested in the federal government. The Court reasoned that foreign affairs powers are different from internal affairs powers. The principle that the federal government can only exercise the powers enumerated in the Constitution applies only to internal affairs - the domestic powers of the federal government were "carved out" of the realm of sovereign powers retained by the states, and are therefore limited. In contrast, the Court found that the several states had never had any foreign affairs powers: powers in foreign affairs transferred directly from the British Crown to the colonies in their "collective and corporate capacity" as the United States of America. Even under the Articles of Confederation, it was intended by the colonies that the federal government possessed full foreign affairs powers, and these powers were retained by the federal government with the adoption of the Constitution. Because the foreign affairs powers of the federal government were not ceded to it by the states, the exercise of those powers did not require an affirmative grant in the Constitution. Rather, the federal government's foreign

15. See infra Sec. II.C.

16. 299 U.S. 304 (1936). 
affairs power is an inherent aspect of the sovereignty of the United States, and is equal in rights and powers to those exercised by all other members of the international community.

While the foreign affairs power in its totality is not expressly granted in the Constitution, various aspects of this power are. For example, the Constitution provides that Congress shall have the power to regulate commerce with foreign nations, to establish uniform rules of naturalization, to define and punish offenses against the law of nations, and to declare war. The President is the commander-in-chief of the armed forces, and has the power to make treaties with the advice and consent of the Senate. The Supreme Court has the power to decide cases arising under treaties made under the authority of the Constitution. Each of these and other powers, and the competency of each branch of the federal government to exercise them will be explored in later sections.

\section{The Role of State and Local Government}

Because the states of the United States are not independent "states" as defined under international law, they do not have the competence to conduct foreign affairs. As the Supreme Court stated in United States $v$. Belmont, ${ }^{17}$ "In respect of . . our foreign relations generally, state lines disappear. As to such purpose the State . . . does not exist." States are expressly prohibited by the Constitution from entering into any treaty, entering into an agreement with a foreign nation without the consent of Congress, or engaging in war unless actually invaded. Moreover, states are prohibited from laying any imposts or duties on exports or imports, and state regulations or taxes that unduly burden foreign commerce are invalid.

The Supremacy Clause of the U.S. Constitution provides that, "This Constitution, and the Laws of the United States . . and all Treaties made ... under the Authority of the United States, shall be the supreme Law of the Land" and the states are bound to observe that law. ${ }^{18}$ Based on the exclusive authority of the federal government in the foreign affairs area, the courts have held that not only treaties, but other international agreements and customary law are part of the supreme law of the United States, and are therefore binding on the states. ${ }^{19}$ Any state law that is inconsistent with a treaty or executive agreement is invalid. Moveover, the Supremacy Clause implies that even when a state law is not inconsistent with federal law, the state law is invalid if the federal government has expressed

17. 301 U.S. 324 (1937).

18. U.S. Const. art. VI. (1942).

19. See Belmont, 301 U.S. at 331; United States v. Pink, 315 U.S. 203, 229-31 
a purpose or policy through "preemption," or by completely occupying a field by legislation. ${ }^{20}$

The commerce power of the federal government also illustrates the plenary nature of the federal foreign affairs power. The Commerce Clause of the United States Constitution provides that the federal government has the power "to regulate Commerce with foreign Nations, and among the several States ...."21 Although at one time the commerce power was interpreted narrowly, under modern doctrine, the power of the federal government to regulate commerce among the states is considered to be very broad. ${ }^{22}$ Consequently, states cannot adopt laws which are inconsistent with federal law. When Congress is silent regarding the federal regulation of commerce, under the Dormant Commerce Clause Doctrine, states may adopt regulations as long as those measures are not inconsistent with federal policy or unduly burdensome on interstate commerce.

As broad as the domestic commerce power may be, the foreign commerce power may be even broader. For example, in the case of Japan Line, Ltd. v. County of Los Angeles, ${ }^{23}$ the Supreme Court struck down a California nondiscriminatory ad valorem tax on foreign-owned cargo containers of international commerce. The Court found evidence that the framers of the Constitution intended the scope of the foreign commerce power to be even broader than the domestic commerce power due to the overriding concern that the federal government must speak with one voice when regulating commercial relations with foreign governments. The Court then found that the California law prevented uniformity "in an area where federal uniformity is essential." 24 Because the tax prevented the government from "speaking with one voice," the Court invalidated the California law.

The courts have also held that the Constitution bars intrusion by the states into foreign affairs matters that are entrusted to the Congress or to the President, even where there is no federal law in the field, and even when the federal government recognizes that there is no conflict between the state law and the conduct of foreign policy. For example, in Zschernig v. Miller, ${ }^{25}$ the Supreme Court struck down an Oregon state probate law, which prevented persons residing in communist countries from inheriting property left to them by Oregon residents. Even though the State Department indicated that the Oregon law did not unduly interfere with the United States' conduct

20. See Hines v. Davidowitz, 312 U.S. 52 (1941).

21. U.S. Const. art. I, sec. 8, cl. 3.

22. See John E. Nowak \& Ronald D. Rotunda, Constitutional Law 136-87 (4th ed. 1991).

23. 441 U.S. 434 (1979).

24. Id. at 455 .

25. 389 U.S. 429 (1968). 
of foreign affairs, the Court reasoned that the Oregon law might disturb foreign relations and required a state probate court to base its decision on foreign policy considerations normally reserved to the federal government. Therefore, the Court held the Oregon statute unconstitutional.

In spite of these constitutional restrictions on state and local intrusion into foreign affairs, state and municipal entities do play some roles in international affairs. As the world becomes ever more interdependent, state and local activities, particularly in the economic area, have an international impact. ${ }^{26}$ One illustration is the various tax incentives and public investment programs undertaken by state and local governments in order to encourage foreign investment and attract foreign-owned businesses. States have sent trade missions abroad to encourage foreign companies to locate production facilities in their states or cities. State and local governments also have an influence as market participants. For example, a number of state and local governments divested their pension funds of South African investments in protest over that country's apartheid policies and practices.

In the diplomatic area, many American cities now have sister cities in a variety of foreign nations, encouraging international exchange and developing international understanding. Local sanctuary movements, where local governments pledged not to enforce federal immigration laws, represented a more direct challenge to federal policies in providing asylum to refugees who were not being protected under federal law. In these ways and others, state and local governments are important participants in international affairs, constitutional prohibitions notwithstanding. These examples have led one commentator to note, "where foreign affairs begin to touch the states, whether in their particular economic interests ... or even in small matters of pride or prejudice or principle, the plenary powers of the national government take on all the colors of federalism."27

\section{The Impact of Supranational Organizations}

With the proliferation of intergovernmental organizations (IGOs) throughout the Twentieth Century, another layer of complexity has been added to the vertical allocation of powers between the federal and state governments. Intergovernmental organizations - whether global, as in the case of the United Nations; regional, as in the case of

26. See Bilder, "The Role of State and Cities in Foreign Relations," in, Louis Henkin et al. (eds.), "Foreign Affairs and the U.S. Constitution 115 (1990) [hereinafter Foreign Affairs]. For an overview of state and local activities in foreign affairs, see generally the materials set out in Thomas M. Franck \& Michael J. Glennon, Foreign Relations and National Security Law: Cases, Materials and Simulations 685-722 (1987).

27. Louis Henkin, Foreign Affairs and the Constitution 247 (1972). 
the Organization of American States; or issue-specific, such as in the case of the General Agreement on Tariffs and Trade (GATT) - often include intergovernmental decision-making bodies and third-party dispute resolution mechanisms that, at least theoretically, have power to set policy, resolve disputes, and establish law for their members. The existence of IGOs raises a variety of questions under United States constitutional law: To what extent do decisions of IGO decision-making bodies create binding obligations within the United States? Does participation in IGOs alter the basic outline of shared powers within each level of government? Between the federal and state levels?

In general, whether a resolution by a decision-making body of an IGO imposes binding obligations on the United States depends on the authority conferred upon such organizations in the constitutive agreements that create them. For example, the International Monetary Fund (IMF) may prescribe rules regarding exchange rates and currency depreciation. The International Civil Aviation Organization may set binding standards applicable to the civil aviation industry. The United Nations Security Council may authorize the use of force to maintain international peace and security.

Thus far, however, there is no IGO to which the United States has ceded sufficient sovereignty paralleling the arrangement between the states and the federal government in the Constitution. This has a variety of implications, particularly regarding the war power, which will be discussed in more detail later. ${ }^{28}$ In general, however, there is no international "Supremacy Clause" that would make a resolution of an IGO the "law of the land" in the United States, as is the case with federal law vis-a-vis state law.

As a result, the international obligations of the United States are subject to normal constitutional processes before they become binding on the nation. The U.N. Security Council resolutions, authorizing the use of force in international police actions, provide an illustration. United States practice in both Korea and Kuwait suggests that the President, absent the negotiation of agreements between the United States and the Security Council pursuant to Article 43 of the United Nations Charter, is constitutionally required to obtain authorization from Congress in order to commit United States troops to combat actions authorized by the Security Council, at least where such action would exceed the President's own war powers. Even were the President to commit troops pursuant to some hypothetical special agreement under the United Nations Charter, the constitutionality of such action would seem to rest on the agreement's prior authorization and

28. See infra Sec. V.C. 
ratification by the Senate exercising its constitutional role in treaty making. ${ }^{29}$

While IGOs do not generally possess the power to create law in the United States similar to the power exercised by the federal government relative to the states, their importance in the vertical allocation of power should not be underestimated. As the world becomes more interdependent, and as nation-states turn to international bodies in the pursuit of their common interests and goals, the impact of supranational organizations on the constitutional processes in the United States will become increasingly more relevant and important. Whether the United States will ever agree to cede key aspects of its sovereignty to a regional or global organization remains to be seen. Nevertheless, recent trends suggest greater contributions to, and cooperation with, supranational organizations, reinforcing expectations of the authoritativeness of supranational organizations in international decision making.

\section{The Horizontal Allocation of Powers}

\section{A. The Doctrine of Separation of Powers and Its Application}

In addition to federalism, another principal feature of the U.S. constitutional system is the principle of separation of powers. While separation of powers is not subject to clear definition, it is, in general, the constitutional effort to allocate different sorts of governmental power into three separate and distinct branches: the legislative, executive, and judicial branches. The Constitution expressly provides for separation of powers by vesting all legislative powers granted by the Constitution in the Congress, ${ }^{30}$ all executive power in the President, ${ }^{31}$ and all judicial power in the Supreme Court and in the "inferior" courts established by Congress. ${ }^{32}$

The primary purpose of separation of powers was to prevent tyranny. To the framers of the Constitution, the concentration of all powers in the same hands was the very definition of tyranny. ${ }^{33}$ The framers were particularly wary of the legislative branch, which they believed would draw all power into its vortex; hence, separation of powers was to prevent legislative encroachment on liberty and private life. ${ }^{34}$ Separating the power to make laws from the power to enforce them ensured that the legislature could not pass oppressive laws knowing that they would be exempt.

29. See Glennon, "The Constitution and Chapter VII of the United Nations Charter," 85 Am. J. Int'l L. 74 (1991).

30. U.S. Const. art. I, sec. 1.

31. Id. art. II, sec: 1.

32. Id. art. III, sec. 1.

33. See The Federalist No. 47 (James Madison).

34. See The Federalist No. 48 (James Madison). 
Separation of powers also served several other purposes. Because separation of powers prevented the accumulation of all power in one branch, it would force public officials to act in the public interest, rather than in their own private interest, by pitting the ambitions of one branch against the others. Separation of powers also provided a partial answer to the framers' fear that factions would take control of the government. Because legislation must be passed by officials with state-wide constituencies (the Senate) and with nation-wide constituencies (the President) before it becomes law, factions with parochial or local interests would be prevented from controlling the government. Finally, because no power could be brought to bear without a broad consensus, separation of powers makes it more difficult for the federal government to act quickly, thereby limiting government action and protecting individual liberty.

A related, though distinct, principle is that of checks and balances. While separation of powers refers to the separation of legislative, executive, and judicial functions into separate, distinct branches, checks and balances refers to the vesting of specific aspects of each of these powers in each of the separate branches. The framers did not want complete separation of powers among the branches. They believed that some overlap in powers was necessary to allow a branch to protect itself from encroachment by the other branches. ${ }^{35}$ A constitutional system of checks and balances ensured that the system would be able to guard against usurpation of authority by any one branch. ${ }^{36}$

The legislative process illustrates the principle of checks and balances under the United States Constitution. To provide a presidential check on congressional power, the Presentment Clause requires that all legislation be presented to the President for signature before it becomes law, and provides the President with the power to veto legislation as he or she sees fit. ${ }^{37}$ This presidential participation in the legislative process protects the executive branch from Congress, and protects the nation as a whole against improvident, ill-conceived, and hastily drawn laws. ${ }^{38}$ The President's veto power, on the other hand, is limited by Congress's power to overrule a presidential veto with a two-thirds vote of both the House of Representatives and the Senate, ${ }^{39}$ thereby precluding the final arbitrary act of a single individual. 40

35. See The Federalist No. 47 (James Madison).

36. See Richardson, "Checks and Balances in Foreign Relations," in Foreign Affairs, supra n. 26 , at 25.

37. U.S. Const. art. I, sec. 7, cl. 2.

38. See INS v. Chadha, 462 U.S. 919, 946-48 (1983).

39. See U.S. Const. art. I, sec. 7, cl. 2.

40. See Chadha, 462 U.S. at 951. 
The separation of the Congress into two chambers, the House of Representative and the Senate, is a further example of checks and balances. When the idea of a single House was discussed at the Constitutional Convention, several of the delegates objected strongly, contending that the accumulation of all legislative power in one body would result in the type of tyranny the Constitution was designed to prevent. Moreover, delegates from the smaller states were concerned that the large states would use their numerical majority to pass laws antithetical to their interests, and the large states were concerned about a legislature that could pass laws favoring the smaller states and, thus, a minority of the people. In response, the Congress was divided into two branches: the House of Representatives, in which the Representatives would be elected in proportion to the number of people within each state, and the Senate, with each state, whether large or small, represented by two Senators. This bicameral arrangement, known as the Great Compromise, ${ }^{41}$ provided another check on unlimited legislative power by requiring that legislation pass both the House of Representatives, which represents the people, and the Senate, which represents the states. ${ }^{42}$

Beyond this broad outline of separation of powers and checks and balances, these concepts are not capable of precise legal definition. While the Constitution divides the federal government into the legislative, executive, and judicial branches, it does not expressly delineate the distinction between their functions. As a result, some commentators have suggested that the principle of separation of powers is a "political doctrine" and not a technical rule of law. ${ }^{43}$ Courts confronted with intergovernmental disputes have often resorted to a variety of interpretative tools when resolving separation of powers questions, a process made particularly difficult when the Constitution is silent or fails to make express provision for particular contingencies. When the text of the Constitution is silent on whether a particular power is within a particular branch of government, the courts have turned to analysis of the framers' intent and to custom and practice as alternative sources of authority. ${ }^{44}$

The problems involved the application of separation of powers is illustrated by the case of INS v. Chadha.45 At issue in Chadha was the constitutionality of a statute that allowed the House of Representatives to overturn decisions of the U.S. Attorney General (an of-

41. See Farrand, supra n. 10, at 91-112.

42. See Chadha, 462 U.S. at 950.

43. See Frankfurter \& Landis, "Power of Congress of Procedure in Criminal Contempts in 'Inferior' Federal Courts - A Study in Separation of Powers," 37 Harv. L. Rev. 1010 (1924).

44. See Glennon, "The Use of Custom in Resolving Separation of Power Disputes," 64 B.U. L. Rev. 109 (1984).

45. 462 U.S. 919 (1983). 
ficer in the executive branch) regarding the deportation of aliens through the use of a simple resolution. Exercising this "legislative veto," the House voted to reverse the Attorney General's decision not to deport a student who had remained in the United States after the expiration of his visa. A majority of the United States Supreme Court held that this legislative veto was unconstitutional. The Court first found that the act of the House was legislative in nature because it altered legal rights, duties and relations outside the legislative branch. However, because the action was undertaken by a simple resolution of the House, and not passed by the Senate and presented to the President, it violated constitutional requirements of bicameralism and presentment. In ruling the legislative veto unconstitutional, the Court looked to both the textual provision of the Constitution detailing the legislative process, and the intent of the framers for including bicameralism and presentment in that process.

The difficulty inherent in the rationale of the majority in Chadha is belied by the opinions of other justices on the Court. Justice Powell, in concurrence, reasoned that the action by the House was essentially judicial in nature, because it determined the rights of an individual rather than the rights of broad classes, and was therefore a violation of separation of powers. ${ }^{46}$ On the other hand, Justice White, in dissent, took a more flexible approach, suggesting that not all legislative vetoes should be unconstitutional. In White's opinion, legislative vetoes allow Congress to maintain a check over the Executive when it delegates authority. ${ }^{47}$ As long as the underlying purposes of the framers are served - preventing overexpansion of presidential and agency power - White believed legislative vetoes should not automatically be voided.48 In support of his argument, Justice White reviewed the fifty-year history of the use of legislative vetoes in a variety of laws and contexts. ${ }^{49}$ Moreover, he noted that the doctrine of separation of powers was not intended to be rigid and inflexible:

[T] he wisdom of the Framers was to anticipate that the Nation would grow and new problems of governance would require different solutions. Accordingly, our Federal Government was intentionally chartered with the flexibility to respond to contemporary needs without losing sight of fundamental democratic principles. This was the spirit in which Justice Jackson penned his influential concurrance in the Steel Seizure Case: . . "While the Constitution diffuses power the better to secure liberty, it also contemplates that

46. See id. at 964-67 (Powell, J., concurring).

47. See id. at 967-68, 972-74 (White, J., dissenting).

48. See id. at 977-79, 1002 .

49. See id. at 968-72. 
practice will integrate the dispersed powers into a workable government." 50

It is from this perspective of cooperation and accommodation that Justice White believed the legislative veto should be evaluated.

\section{B. Separation of Powers and Foreign Affairs}

Principles of separation of powers apply with equal force in foreign affairs as they do in domestic affairs. But because many foreign affairs functions are not clearly delineated in the Constitution nor attributed to particular branches, many separation of powers issues are left unresolved. Even when the Constitution expressly commits certain foreign affairs powers to a specific branch, the scope of those powers remains subject to controversy, particularly when the exercise of those powers by one branch impinges on powers that traditionally fall within the domestic powers of another branch. Moreover, because the courts are often hesitant to adjudicate in the foreign affairs arena, issues of separation of powers are resolved, if at all, by political struggles between the President and Congress, with the President most often winning.

The Constitution does make explicit, although sparse, allocation of foreign affairs powers among the three branches of the federal government. For example, the Constitution expressly provides that the President is the commander in chief of the armed forces of the United States, ${ }^{51}$ and directs that the President "shall take care that the laws be faithfully executed."52 In addition, the President has the power to appoint ambassadors, other public ministers and consuls with the advice and consent of the Senate, ${ }^{53}$ and has the sole power to receive ambassadors and other public ministers from foreign nations. ${ }^{54}$ Congress, on the other hand, in addition to its general powers to appropriate funds for the functioning of the federal government (commonly known as the "power of the purse") and its power to make all laws "necessary and proper" for executing the powers granted by the Constitution, is also given the power to regulate commerce with foreign nations; to define and punish piracy, felonies committed on the high seas, and offenses against the law of nations; to declare war; and to raise, support and provide rules regulating the armed forces of the United States. ${ }^{55}$

Due to the vagaries of each of these enumerated powers, however, issues of separation of powers often arise even when the Presi-

50. Id. at 978 (citing Youngstown Sheet \& Tube Co. v. Sawyer, 343 U.S. 579, 635 (1952)).

51. U.S. Const. art. II, sec. 2 , cl. 1 .

52. Id. art. II, sec. 3 .

53. Id. art. II, sec. 2 , cl. 2.

54. Id. art. II, sec. 3 .

55. Id. art. I, sec. 8. 
dent or Congress exercises its exclusive powers, leading to assertions of interference by the other branches. For example, there is continuing controversy over the competency of the President to commit American forces to foreign wars based upon his role as commander in chief without obtaining an express declaration of war by Congress. Conversely, it is unclear how far the Congress can limit the President's decisions as commander in chief when exercising its power to regulate the armed forces.

Issues of separation of powers are also complicated by the constitutional blurring of the prescribing (law-making) function in foreign affairs. In domestic affairs, the Congress is generally considered to be the predominant law-making body in the federal government. However, the Constitution expressly provides that the President has the power to make treaties with foreign nations, with the advice and consent of two-thirds of the Senate. ${ }^{56}$ This bifurcation of the prescribing function raises a variety of separation of powers questions: To what extent may the Senate alter treaties already negotiated by the President in its advice and consent function? To what extent is Congress as a whole obliged to pass domestic legislation to comply with international obligations undertaken pursuant to treaties? Can Congress defeat treaties ratified by the Senate by passing conflicting domestic legislation? Furthermore, what role does Congress play in the adoption of executive agreements with foreign nations and the development of customary international law?

Finally, a whole host of foreign affairs powers are not even mentioned by the Constitution. No mention is made of which branch has the power to recognize or derecognize foreign nations. While the Constitution does vest the power to declare war in the Congress, no mention is made of which branch has the power to terminate a state of war. The Constitution also fails to make mention of any "emergency" powers that might be available to the President when an international crisis threatens domestic security, or when the conduct of foreign affairs requires emergency measures within the United States.

In resolving separation of powers issues in foreign affairs, Justice Jackson's famous formula is often cited. In Youngstown Sheet \& Tube Co. v. Sawyer, ${ }^{57}$ Justice Jackson in a concurring opinion suggested:

1. When the President acts pursuant to an express or implied authorization of Congress, his authority is at its maximum, for it includes all that he possesses in his own right plus all that Congress can delegate. ...

56. Id. art. II, sec. 2, cl. 2.

57. 343 U.S. 579 (1952). 
2. When the President acts in absence of either a Congressional grant or denial of authority, he can only rely on his own independent powers, but there is a zone of twilight in which he and Congress may have concurrent authority, or in which its distribution is uncertain. ...

3. When the President takes measures incompatible with the expressed or implied will of Congress, his power is at its lowest ebb, for then he can rely only upon his own constitutional powers minus any constitutional powers of Congress over the matter. ... .58

Given the general lack of clear separation of foreign affairs powers under the Constitution, it has been suggested that foreign affairs powers fall generally in Justice Jackson's second category of concurrent presidential and congressional power. However, neither Justice Jackson nor any other authority provides clear guidance about which branch should prevail when conflicts in the exercise of these concurrent powers arise. As a result, the scope of foreign affairs powers as currently exercised by the branches has been arrived at by a variety of means including extrapolation from expressly granted powers, practice, custom, and accommodation among the branches.

How some of the issues in separation of powers in foreign affairs have been resolved in specific instances will be discussed in more detail later. Suffice it to say at this point that separation of powers remains a vital and hotly disputed principle in the conduct of U.S. foreign policy, with resolution often taking on the character of political accommodation rather than the application of a legally-defined principle.

\section{The External Competence of the Executive Power: Foreign Affairs Power of the President}

\section{A. The President as Both Head of State and Head of Government}

In the United States constitutional system of government, the President serves as both the head of state and the head of government. This arrangement is unique among the major powers of the world, leading one commentator to suggest that the office of the President is like combining the office of the British sovereign with that of the Prime Minister. ${ }^{59}$

The Constitutional provision that created this arrangement simply provides, "The executive power shall be vested in a President of the United States of America."60 The consequences of the dual function of the President as head of state and head of government are

58. Id. at 635-37 (Jackson, J., concurring).

59. See Arthur S. Miller, Presidential Power in a Nutshell 21-24 (1977).

60. U.S. Const. art. II, sec. 1. 
several: most importantly, as head of state, the President has certain "inherent" powers, and is entitled to certain executive privileges of presidential confidentiality. Moreover, although the Constitution provides for shared foreign affairs powers between the President and Congress, the President often has the "upper hand" in struggles to assert foreign policy prerogatives. Consequently, if sovereignty is found anywhere in the federal government, it is found in the President.

\section{B. Presidential Foreign Affairs Powers in General}

The President is generally considered to have the paramount power to represent the United States in relations with other nations. In the leading case in the area, United States v. Curtiss-Wright Export Corp. ${ }^{61}$ Justice Sutherland summarized the President's power in this way:

[T]he President alone has the power to speak or listen as a representative of the nation. ... As Marshall said in his great argument of March 7, 1800, in the House of Representatives, "The President is the sole organ of the nation in external relations, and its sole representative with foreign nations." 62

Justice Sutherland then went on to say that the President's authority as "sole organ" for the United States with regard to foreign nations is "delicate, plenary, and exclusive," and does not require an act of Congress as a basis for its exercise.

The decision to make the President the sole representative of the United States in foreign affairs derived from past experiences under the Articles of Confederation. Under the Articles, there was no executive power or officer in the federal government. Instead, Congress itself conducted all foreign affairs activities, including receiving ambassadors and negotiating treaties. However, collective responsibility in foreign relations proved to be unworkable: Congress was often slow to act due to the deliberative process itself; disputes among members of Congress led to conflicting communications with foreign officials, and secrecy during treaty negotiations was often impossible to maintain. Moreover, Congress could not guarantee that the several states would comply with the international obligations it undertook. As the credibility and the prestige of the new United States in foreign relations declined, the need for an executive agent to represent the United States was keenly felt. This was one of the reasons the framers of the Constitution separated the executive powers from

61. 299 U.S. 304 (1936).

62. Id. at 319 . 
the Congress, placing them within an executive branch under the authority of the President.

While the President is generally considered to have full, plenary powers to represent the United States in foreign affairs, there is no express provision for such power in the Constitution. The express powers of the President include the power to make treaties, with the concurrence of two-thirds of the Senate, and the power to appoint ambassadors, public ministers and consuls with the advice and consent of the Senate. ${ }^{63}$ The President also has the express authority to receive ambassadors and other public ministers. ${ }^{64}$ Other general grants of executive power that have foreign affairs implications include the vesting of all executive power in the President, ${ }^{65}$ the President's authority as commander-in-chief of the armed forces, ${ }^{66}$ and the President's obligation to "take care" that the laws of the United States be "faithfully executed."67 Despite these limited grants of foreign affairs powers, the President's authority in practice is much broader.

The most persuasive rationale for broad presidential power in foreign affairs was asserted by Alexander Hamilton, one of the framers and an early supporter of the Constitution. In Hamilton's view, broad presidential power in foreign affairs was implicit in the general grant of all executive powers under Article II. Any foreign affairs powers not expressly granted to the Congress devolved by implication to the President by operation of the Executive Power Clause. ${ }^{68}$ For example, the power to recognize and derecognize foreign states is generally implied from the President's power to receive foreign ambassadors and consuls, such as when the first President, George Washington, recognized the revolutionary government of France by receiving "Citizen" Genet, and then later terminated relations with France by having Genet recalled. ${ }^{69}$ In addition, the President's sole power to conduct treaty negotiations with foreign powers and keep the contents of such negotiations secret is implied from the President's power to appoint individuals to conduct foreign affairs negotiations. President Washington, for example, refused to comply with a request by the House of Representatives to give Congress papers relating to the negotiation of the Jay Treaty of 1796, claiming exclusive powers in the area of treaty negotiation and thereby limiting Congress's role.

63. U.S. Const. art. II, sec. 2 , cl. 2 .

64. Id. art. II, sec. 3.

65. Id. art. II, sec. 1 , cl. 1.

66. Id. art. II, sec. 2 , cl. 1.

67. Id. art. II, sec. 3.

68. See Nowak \& Rotunda, supra n. 22, at 198.

69. See also United States v. Pink, 315 U.S. 203 (1942) (holding that the President has the sole authority not only to determine which governments to recognize, but also the power to determine the policy which is to govern the question of recognition). 
The Supreme Court affirmed a broad interpretation of the President's power as the sole organ for the conduct of foreign affairs in the Curtiss-Wright case. ${ }^{70}$ In Curtiss-Wright, the Congress, by joint resolution, provided that the President could make findings and issue proclamations banning arms sales to certain countries to preserve regional peace. The President subsequently issued a proclamation banning arms sales to Bolivia. The defendants, who were indicted for selling arms to Bolivia in violation of the order, challenged it as an unconstitutional delegation of legislative power to the President by Congress.

The Supreme Court, however, upheld the order. The Court assumed that if this delegation had taken place in the context of domestic affairs, it would be unconstitutional. However, because the delegation was in the context of foreign affairs, where the federal government has exclusive and plenary power, it was a permissible delegation. Moreover, the Court found that the authority of the President to act in this area was not only supported by the act of Congress, but also by the President's own powers in foreign affairs, which the Court characterized as plenary and subject only to constitutional limitations. Taking a pragmatic view of modern foreign affairs, Justice Sutherland, writing for the majority, reasoned that the need for greater discretion and efficiency in foreign affairs, the need for secrecy in international negotiations, and the greater expertise and access to confidential information available to the President from the diplomatic staff further supported broad presidential authority in foreign affairs. ${ }^{71}$

Despite the broad affirmance of presidential power in foreign affairs in Curtiss-Wright, the President's exercise of foreign affairs powers is not without limit, particularly when the President acts contrary to congressional will. For example, in Youngstown Sheet \& Tube Co. v. Sawyer, ${ }^{72}$ (the "Steel Seizure Case"), President Truman seized steel mills during the Korean War to prevent their closure due to a labor contract dispute. Truman based his power not on any legislative act, but on his broad powers as commander-in-chief of the armed forces, the general grant of executive powers under Article II of the Constitution, and the Faithful Execution Clause. The President argued that the aggregate of these executive powers gave him the "inherent power" to prevent a strike that would disrupt steel production, and thereby threaten the well-being and safety of the nation during war.

The Supreme Court rejected Truman's assertions and struck down the steel seizure order. A majority of the Court reasoned that

70. 299 U.S. 304 (1936).

71. See id. at 320 .

72. 343 U.S. 579 (1952). 
the President's power must stem either from an act of Congress or from the Constitution itself. The Court found, in this case, that there was no congressional act which supported the President's action. In fact, the Court found that the Congress had specifically refused to grant the President the emergency power to settle labor disputes through seizures. ${ }^{73}$

The Court also rejected Truman's constitutional arguments. The President's aggregate executive powers did not support the seizures; rather, his actions were legislative in nature. The Court held that the Constitution made it clear that the Congress had the sole lawmaking power, and that the President is bound to execute the laws passed by Congress under the Faithful Execution Clause. The fact that other Presidents had seized domestic enterprises in order to settle labor disputes did not strip the Congress of its exclusive legislative power.

Unlike the Curtiss-Wright case, in which the President acted pursuant to express congressional delegation, Truman's actions in the Youngstown case were in direct contravention of congressional will, and involved actions that were primarily domestic in nature, namely the seizure of domestic steel plants to support the production of materials needed in the war effort in Korea. As suggested by Justice Jackson in his famous concurrence in the Youngstown case, the president's power is at its lowest ebb when action is taken that is "incompatible with the expressed or implied will of Congress," leaving the President to rely only on his or her "own constitutional powers minus any constitutional powers of Congress over the matter."74 The President's foreign affairs powers are, therefore, limited by the Congress's powers in a variety of areas, as will be explored in more detail below. But because most foreign affairs powers fall into Justice Jackson's second category - a "zone of twilight" in which the President and Congress may have concurrent authority - assertions of exclusive presidential control over foreign affairs, and concomitant assertions of a congressional role in the formulation of foreign policy, continue to characterize the struggle for control over the foreign policy of the United States.

\section{The Treaty Power, Other International Agreements, and the President's Role in the Development of Customary International Law}

The Constitution expressly empowers the President "by and with the Advise and Consent of the Senate, to make treaties provided two thirds of the Senators present concur." ${ }^{5}$ While the Constitution on

73. See id. at $585-86$.

74. Id. at 637 (Jackson, J., concurring).

75. U.S. Const. art. II, sec. 2 , cl. 1. 
its face only authorizes the President to enter into agreements with foreign nations through the treaty power, three different modalities through which international agreements are made by the United States are supported by practice and affirmed by the courts: treaties, congressional-executive agreements, and sole executive agreements. In addition, the President, as the sole representative of the United States in foreign affairs, has a role in the progressive development of customary international law.

The treaty-making power, as mentioned above, is the only method of concluding international agreements expressly recognized under the Constitution. Because the treaty-making power is an inherent aspect of nationhood and sovereignty, the subject of a treaty may properly include any aspect of that sovereign power, subject only to constitutional limitations. ${ }^{76}$ The Constitution itself does not limit the subject of treaties to "matters of international concern," and assertions to this effect have long been rejected. ${ }^{77}$

As the sole representative of the United States in foreign affairs, and through the exercise of the treaty power, the President appoints and supervises the individuals who negotiate agreements with a foreign power. The President then transmits the concluded treaty to the Senate for approval. If the Senate approves the treaty by a twothirds vote, the President then ratifies it, and the treaty becomes binding on the United States.

The constitutional consequences of concluding treaties through the Article II process are numerous: The Constitution expressly provides that treaties concluded in this manner are the supreme law of the land, binding not only on the federal government, but on the several states as well. ${ }^{78}$ In addition, the judicial branch of the federal government has the express power to review cases and controversies that arise under treaties so concluded, ${ }^{79}$ and Congress can implement and enforce treaty obligations through the passage of "necessary and proper" domestic legislation. ${ }^{80}$

Under separation of powers principles, the Congress is normally the sole legislative organ, with the President's role limited to recommending legislation, and the signing or vetoing of laws passed by Congress. In the area of international relations, however, the Constitution gives the President primary law-making authority. The President was provided with the primary authority for a variety of

76. See infra Sec. VI.D.

77. See Restatement (Third) of the Foreign Relations Law of the United States $\S 302$ Rep. Note 2 (1987) [hereinafter Restatement]. See also infra Sec. VI.D.

78. U.S. Const. art. VI, cl, 2. The extent to which a treaty upon ratification, or any other international agreement, is automatically binding as supreme law depends on whether it is a "self-executing" agreement. See infra Sec. V.B.

79. U.S. Const. art. III, sec. 2 , cl. 1.

80. Id. art. I, sec. 8, cl. 18. 
reasons. First, political theory and the example of British constitutional practice at the time of the drafting of the Constitution suggested that the power to bind the nation as a whole normally rested in the chief executive power, such as the British crown. Moreover, problems under the Articles of Confederation, where Congress had the sole responsibility for negotiating and ratifying treaties, and the need for "secrecy and dispatch" in diplomatic activities demonstrated the need for the creation of an executive agent vested with the treatymaking power. ${ }^{81}$

Although the Constitution only expressly authorizes the President to conclude treaties, the President often enters into agreements with foreign nations without the consent of two-thirds of the Senate. The validity of such executive agreements has been defended on the basis of history, constitutional interpretation, and legal utilitarianism. ${ }^{82}$ Some commentators argue that the Constitution expressly recognizes the existence of international agreements other than treaties when it provides that "No state shall, without the consent of Congress . . . enter into any agreement or compact with another state, or with a foreign power." ${ }^{33}$ Regardless of whether the Constitution expressly or implicitly recognizes alternative modalities of creating international agreements, executive agreements have been an accepted method of lawmaking since the beginning of the republic.

Executive agreements generally fall into two categories: congressional-executive agreements and sole executive agreements. Congressional-executive agreements include international agreements already concluded by the President which are submitted to both Houses of Congress for a joint resolution by majority vote, rather than by vote of two-thirds of the Senate only. They also include legislation adopted by Congress that requires the President to conclude an international agreement to execute the legislation, or that authorizes the President to negotiate and conclude an agreement, or to ratify an agreement already negotiated.

The potential scope of congressional-executive agreements includes anything within the constitutional power of the President and the Congress, and because the federal government has plenary power in foreign affairs, the scope of such power is very broad, subject only to the same constitutional limitations that apply to treaties. Moreover, since a congressional-executive agreement can also be adopted through the treaty-making process, it has been suggested that either modality may be used, the choice depending merely on political con-

81. See The Federalist No. 64 (John Jay).

82. See "Note: Origins of the Executive Agreement," in Franck \& Glennon, supra n. 26 , at 236 .

83. U.S. Const. art. I, sec. 10. See McDougal \& Lans, "Treaties and Congressional-Executive or Presidential Agreements: Interchangeable Instruments of National Policy," 54 Yale L.J. 181 (1945). 
siderations, and that congressional-executive agreements have the same binding effect as supreme law as treaties.

Congressional-executive agreements have been used with increasing frequency for the conclusion of tariff and other trade agreements. Their popularity in the trade area is probably due to the recognition of the House of Representatives' special role as the originator of bills that propose raising of revenues. ${ }^{84}$ In addition, United States trade law provides an example of the pre-authorization of executive agreements by Congress. For example, United States trade law authorizes the President to make executive agreements to lower tariffs with foreign nations. ${ }^{85}$ The decision to use the congressionalexecutive agreement modality in international trade agreements reflects the recognition that successful policy in this area requires the support and concurrence of both Houses of Congress, not just the Senate.

The other modality available to the President for making international agreements is the sole executive agreement, also known as presidential agreement. It is suggested that such agreements rest on the President's sole plenary foreign affairs powers, such as the commander-in-chief power or the power to recognize foreign nations. However, the cases are ambiguous as to whether the President's authority to conclude sole executive agreements derives solely because of a history of Congressional acquiescence, or because Congress by its silence implicitly authorizes Presidential activity in an area of concurrent authority. For example, in Dames \& Moore v. Regan, ${ }^{86}$ the Supreme Court upheld an executive agreement through which President Carter settled claims against Iran arising from the Iranian hostage incident. In upholding the Executive orders that implemented the settlement, the Court noted both a history of implicit congressional approval of the practice of claims settlement by sole executive agreement, and a history of congressional acquiescence in the President's power to settle claims without the advice and consent of the Senate, thereby demonstrating a "gloss" on executive power.

As the sole representative of the United States in international affairs, the President also contributes to the process through which customary international law is made. It is through the President that the United States asserts claims against foreign nations, and it is to the President that foreign nations turn when asserting claims against the United States. It is through the President that authoritative statements of United States policy are communicated to the international community. The President can also waive the rights of the United States, disregard international obligations, or conduct af-

84. U.S. Const. art. I, sec. 7.

85. See 19 U.S.C. \& 2111 (1988).

86. 453 U.S. 654 (1981). 
fairs in such way as to suggest the emergence of a new norm of customary law. The President appoints and supervises United States diplomats, such as the United States Ambassador to the United Nations. Through each of these modalities and others, the President contributes to the definition and exercise of international practice necessary for the development of customary international law.

An example of the President's role in the development of customary law is illustrated by President Reagan's action regarding the United Nations Convention on the Law of the Sea. After the Convention was adopted at the Third United Nations Conference on the Law of the Sea (UNCLOS III), the Reagan Administration decided not to sign the treaty due to objections regarding provisions regulating the mining of the deep sea-bed. However, President Reagan issued a statement stating that many provisions of the treaty restated or clarified the customary law in the area, or provided useful developments of the law. Consequently, while the United States would not sign the treaty, the Administration indicated that it would comply with various aspects of the treaty including those relating to navigation and overflight, and the recognition of a 200-nautical-mile exclusive economic zone. ${ }^{87}$ Those seeking to determine the content of the customary international law of the sea will turn to such authoritative statements as evidence of state practice.

\section{The War Power}

The President does not have the authority to declare war; such authority is expressly reserved to the Congress by the Constitution. ${ }^{88}$ The President, however, is designated as the commander-in-chief of all United States forces. ${ }^{89}$ But because the lines between executive and legislative power are not clearly established by the Constitution, the constitutional scheme of shared war powers has long led to debate about the proper roles of the President and Congress in the conduct of war.

The commander-in-chief power, read in conjunction with the Executive Power and Faithful Execution Clauses, has been used as a basis for expanding the President's war powers justifying presidential authorization of military actions without the consent of Congress. The first theory used to support the expansion of presidential war powers was self-defense, that is, the President has the authority to order defensive military action in response to actual aggression without congressional approval. The self-defense theory was approved by

87. "President's Statement on United States Ocean Policy," 19 Weekly Comp. Pres. Doc. 70-71 (March 14, 1983).

88. U.S. Const. art. I, sec. 8.

89. Id. art. II, sec. 2. 
the Supreme Court in the Prize Cases, ${ }^{90}$ where the Court affirmed President Abraham Lincoln's order to blockade southern states without a congressional declaration of war during the Civil War. In affirming the order, the Supreme Court ruled that while the President did not have the power to initiate war, he did have the authority, if not the duty, to respond to aggressions against the United States without waiting for congressional action. The President has not only the authority to determine if hostilities are sufficient to require a response in self-defense, but also to determine the amount of force to be used in repelling the attack.

Other theories supporting the expansion of presidential war powers include the neutrality theory - the President has the power to authorize foreign military action to protect United States nationals and property while remaining neutral in the conflict - and the power to authorize military action pursuant to collective security regimes such as the Organization of American States (OAS), the North Atlantic Treaty Organization (NATO), and the South East Asian Treaty Organization (SEATO). For example, President Theodore Roosevelt relied on the neutrality theory to send troops into Panama in 1903, even though the supposedly neutral troops were used to fight the Colombian Army, and President Truman used the collective security theory to justify the United States military operations in Korea as a "police action" under the United Nations.

But despite this seeming expansion of presidential power, domestic political realities, particularly in light of the Vietnam War experience, have led more recent Presidents to seek congressional approval before committing United States forces abroad, or to support the legality of their actions on general congressional authorizations. For example, President Bush sought and secured congressional approval before committing United States troops to actual conflict in the recent Iraq-Kuwait war. ${ }^{91}$

Due to discontent over the President's ability to conduct informal wars without congressional authority, the Congress passed the War Powers Resolution ${ }^{92}$ in 1973 in order to restore what some believed was the original balance of war powers intended by the Constitution. As discussed below, there are questions about the War Power Resolution's constitutional legality. ${ }^{93}$ Nevertheless, it reaffirms the President's power to send troops into combat if the United States or its territories are attacked. ${ }^{94}$ However, it also recognizes Congress's shared responsibility by providing that the President "in every possi-

90. 67 U.S. (2 Black) 635 (1863).

91. See Stromseth, "Rethinking War Powers: Congress, the President and the United Nations," 81 Geo. L.J. 597 (1993).

92. 50 U.S.C. $\$ \S 1545-48(1973)$.

93. See infra Sec. V.C.

94. 50 U.S.C. $\S 1542(c)(3)$. 
ble instance shall consult with Congress before introducing United States Armed Forces into hostilities."95

\section{E. The Role of Executive Departments and Agencies in External Affairs}

Throughout most of the early history of the United States, the executive branch remained relatively small. The President fulfilled executive functions with the help of only a few executive departments and agencies. However, the needs of modern governance in response to the Great Depression of the 1930s led to an expansion of the executive branch and the rise of the so-called "Administrative state." From the New Deal Era on, the federal bureaucracy has grown to its current size, with many domestic executive departments and agencies charged with implementing, under the supervision of the President, an ever growing number of programs authorized by Congress.

The rise in the number of administrative agencies charged with implementing domestic programs is paralleled by an increase in the number of agencies dedicated to foreign affairs functions. The United States Department of State, which was created in 1789 to serve as the primary diplomatic organ of the United States, has steadily increased in size in response to the United States growing importance in international affairs. ${ }^{96}$ The War Department, the name of which was changed to the Department of Defense after World War II, increased in size as a result of America's expanding military involvements and obligations throughout the world. In addition, a variety of new agencies were created in the Twentieth Century devoted to international affairs: The National Security Council ("NSC") and the Central Intelligence Agency ("CIA") were created in 1947 to oversee international security interests. The Office of the United States Trade Representative has played an integral role in conducting international trade relations in an era of ever increasing international economic interdependence, while the Agency for International Development ("AID") is the primary organ for the provision of foreign aid. A number of agencies that are primarily engaged in domestic affairs, such as the United States Environmental Protection Agency, have divisions devoted to aspects of international relations that fall within their jurisdictions.

Despite the growth in the size and complexity of the United States administrative state, the President retains control over the function of the executive department, agencies, and councils, and remains ultimately responsible for their conduct. In general, the President maintains control through the power to appoint and remove

95. Id. $\S 1543$.

96. See Act of July $27,1789, \S 1,1$ Stat. 28 . When originally established, the Department of State was called the Department of Foreign Affairs. 
government officials. In addition, the President has more direct control over foreign affairs function by setting policy and designating those officials that will act on behalf of the United States. For example, while the North American Free Trade Agreement ("NAFTA") among the United States, Mexico and Canada was negotiated by the Office of the United States Trade Representative, the Trade Representative was designated by the President, and subject to the President's direction.

In some cases, certain officials and organs of the United States have the authority to conduct foreign relations with certain autonomy. For example, while the President has the authority to represent the United States in treaty negotiations, that function is usually exercised by the Secretary of State, or other ambassadors and representatives. Congress has also expressly given the power to conclude agreements with foreign nations to certain agencies: the Postal Service is authorized to conclude postal agreements with foreign nations, ${ }^{97}$ and the American Institute on Taiwan has the power to make agreements with Taiwan. ${ }^{98}$ However, in each of these cases the President still retains ultimate authority. The Secretary of State or other ambassadors cannot conduct treaty negotiations without the provision of full powers by the President, and are ultimately subject to the President's appointment and removal power. Both the Postal Service and the American Institute can only conclude agreements with the direction and consent of the President. So while executive departments and agencies play an important role in the conduct of American foreign affairs, the President remains the "sole representative" of the United States in international affairs.

\section{The Role of Congress in Foreign Affairs}

\section{A. Shared Competence of Congress in Foreign Affairs}

Constitutional grants of foreign affairs powers to Congress clearly establish Congress's role in the formation of United States foreign policy, making American foreign policy a shared responsibility of the executive and legislative branches. What is less clear is the extent to which the President and Congress function as constitutional equals in foreign affairs, or whether the President has the primary responsibility with Congress acting only as a ratifier of presidential initiatives. This question has served as the basis of a continuing controversy between the President and Congress that has existed throughout the history of the United States. But despite the controversy, it is also clear that congressional participation is an important,

97. See 39 U.S.C. $\$ 407$ (1988).

98. See 22 U.S.C. $\$ 3305$ (b) (1988). See also Restatement, supra n. 77, § 303 Rep. Note 10. 
and necessary, aspect of successful and effective foreign policy in the United States.

The controversy has become more complicated in modern history due to an expanding notion of foreign affairs in general. As the international community becomes increasingly interdependent in the economic, social, environmental, human rights and other areas, the line between international and domestic affairs has blurred. Many aspects of governance that were traditionally considered domestic in nature now have international ramifications. On the other hand, regional and global efforts are often required to solve domestic problems, such as in the areas of trade and economy.

The Constitution specifically grants Congress certain foreign affairs powers and does so in broad terms. Congress has the exclusive power to regulate all foreign commerce, ${ }^{99}$ the power to provide for the common defense, ${ }^{100}$ and the power to "define and punish Piracies and Felonies committed on the High Seas, and Offences against the law of Nations." 101 In addition, Congress has the power to declare war, to make rules of war, grant letters of marque and reprisal, ${ }^{102}$ and to raise, support, and regulate an army and navy. ${ }^{103}$ Moreover, the Senate has a role in treaty making and the appointment of ambassadors. ${ }^{104}$

These express grants of foreign affairs powers have been used to support broad congressional action in the formation of American foreign policy. In particular, the commerce power has been an increasingly important tool in the regulation and conduct of foreign affairs. With the increasing importance of international business transactions, and the growing interdependence of the world's economies, Congress's exercise of the commerce power has a tremendous impact on the development of United States foreign policy.

In addition to express grants of foreign affairs powers, the Congress is also granted a variety of general legislative powers that have an impact on foreign affairs, and from which expanded congressional foreign affairs powers have been implied. The most important of these powers is the power

To make all Laws which shall be necessary and proper for carrying into Execution the ... Powers vested by this Constitution in the Government of the United States or in any Department or Officer thereof. ${ }^{105}$

\footnotetext{
99. U.S. Const. art. I, sec. 8, cl. 3.

100. Id. sec. 8, cl. 1 .

101. Id. sec. 8 , cl. 10 .

102. Id. sec. 8, cl. 11 .

103. Id. sec. 8, cls. 12,13 .

104. Id. art. II, sec. 2 , cl. 2 .

105. Id. art. I, sec. 8, cl. 18.
} 
The Necessary and Proper Clause impliedly requires the President to seek congressional legislation to enact foreign policy, and the appropriations mechanism serves as an effective congressional check on presidential foreign affairs powers. In addition, Congress's exclusive and plenary power over admiralty and maritime matters is implied from the exclusive grant of admiralty and maritime jurisdiction to the federal courts, ${ }^{106}$ as read in conjunction with the Necessary and Proper Clause. The Necessary and Proper Clause gives Congress the power to adopt domestic legislation to implement treaties negotiated and ratified pursuant to the treaty power.

Another important legislative power for the exercise of foreign affairs is the spending power. The Constitution specifically grants Congress the power to provide for the common defense and general welfare of the United States. ${ }^{107}$ The spending power serves as the basis not only for raising money for the national defense, but also for the provision of foreign aid programs, an important aspect of modern American foreign relations. Other Congressional powers that have foreign affairs implications include the power to borrow money on the credit of the United States, ${ }^{108}$ the power to establish uniform rules of naturalization, ${ }^{109}$ the power to regulate the value of money, ${ }^{110}$ the postal power, ${ }^{111}$ and the investigatory power.

Beyond these express and implied grants of foreign affairs powers, the Congress has a constitutionally implied power to regulate foreign affairs. The Supreme Court affirmed the existence of this broad, implied power in Perez $v$. Brownell, ${ }^{112}$ a case which involved Congress's power to pass legislation that would have the effect of revoking United States citizenship of an American citizen who voted in a foreign election. While the exact holding of the case was later overruled, the Court's conclusion that the Congress has the authority to legislate in foreign affairs matters has not been questioned. In holding that Congress acted within its foreign affairs powers, Justice Frankfurter wrote:

[W] hat is the source of power on which Congress must be assumed to have drawn? Although there is in the Constitution no specific grant to Congress of power to enact legislation for the effective regulation of foreign affairs, there can be no doubt of the existence of this power in the law-making organ of the nation .... [A] federal Government to conduct

106. Id. art. III, sec. 2 .

107. Id. art. II, sec. 8 , cl. 1.

108. Id. sec. 8 , cl. 2.

109. Id. sec. 8 , cl. 4 .

110. Id. sec. 8 , cl. 5 .

111. Id. sec. 8 , cl. 7 .

112. 356 U.S. 44 (1958), overruled on other grounds Afroyim v. Rusk, 387 U.S. 253 (1967). 
the affairs of that nation must be held to have granted that Government the powers indispensable to its sovereign functioning effectively in the company of sovereign nations. The Government must be able not only to deal affirmatively with foreign nations ... [i]t must also be able to reduce to a minimum the frictions that are unavoidable in a world of sovereigns sensitive in matters touching their dignity and interest. 113

Justice Sutherland expressed similar reasoning in the CurtissWright ${ }^{114}$ case. According to Justice Sutherland, the United States possesses a "foreign affairs power" that is an inherent attribute of sovereignty. Congress's implied power to regulate foreign affairs is the legislative component of United States sovereignty.

The exact scope of Congress's inherent foreign affairs power has not been settled. However, as with other exercises of congressional power, the Congress is limited by grants of foreign affairs powers to the other branches of the federal government, and by other constitutional limitations protecting individual rights.

\section{B. The Treaty Power}

One area of international relations where the Congress has both an express and implied role is in the making of international agreements. The degree and modality of Congressional participation in international law-making depends on what type of agreement is being considered: a treaty, a congressional-executive agreement, or a sole executive agreement.

The Constitution gives the Senate an express role in the process of treat adoption. It specifically provides that the President makes a treaty by ratifying or acceding to it only after the two-thirds of the Senate gives its consent. ${ }^{115}$ While Senate consent is required before the President can ratify a treaty, the President is under no obligation to ratify once the Senate has given its consent. The President retains complete discretion over the decision to "make" treaties, and the Senate cannot force a President who does not wish to to ratify a treaty. ${ }^{116}$

The Senate cannot amend or enter reservations to a treaty negotiated by the President. It can, however, condition its consent on modifications or reservations, or on a certain interpretation of the treaty's meaning. The President can ignore such conditions, but cannot proceed to ratify the treaty until such conditions are met. ${ }^{117}$

113. Id. at 57 .

114. 299 U.S. 304 (1936). See also Fong Yue Ting v. United States, 149 U.S. 698, $711,713(1893)$.

115. U.S. Const. art. II, sec. 2 , cl. 2.

116. See Restatement, supra n. $77 \S 303$ Comment d.

117. See id. 
The Constitution also provides that the President may make treaties with the "advice and consent" of the Senate. It has been acknowledged, however, that Senate "advice," as distinguished from its "consent," is not a necessary component of treaty negotiation. At the time the Constitution was drafted, the drafters probably envisioned a Senate role whereby the Senate, which at that time would only be twenty-six Senators, would serve as a type of advisory council, consulting with the President as a treaty was negotiated. ${ }^{118}$ No President ever used the Senate in this role, and the Senate since acquiesced, particularly when the number of Senators began to grow as the nation expanded.

Both houses of Congress have a role in the adoption of congressional-executive agreements. Because a congressional-executive agreement requires congressional legislation at some point, both the House and the Senate have to adopt that legislation by majority vote before the agreement can become law. The Senate does not have to adopt the agreement by a two-thirds majority, as when it gives consent to a treaty, perhaps making it easier to obtain Senate approval. This is offset by the fact that a House majority must also be obtained, which may be especially important for agreements in areas where the House has the power to originate legislation.

Sole executive agreements, being based on the President's plenary foreign affairs powers, by their nature do not need congressional authorization before they become binding, and therefore, there is theoretically no Congressional role. Questions of whether the President can make an agreement inconsistent with an act of Congress, or whether Congress can adopt legislation regulating sole executive agreements have not been authoritatively settled. ${ }^{119}$

Treaties adopted pursuant to constitutional procedures are given the same status as domestic legislation. The Constitution provides that treaties, as well as federal statutes, are the supreme law of the land, binding on the States. Theoretically, every treaty ratified with the consent of the Senate is supreme law. The Supreme Court, however, recognizes that some treaties, non-self-executing treaties, do not automatically have this authoritative effect. A non-self-executing treaty, such as a treaty that is more in the nature of a contract between two nations, where one party engages to perform an act, requires domestic legislation before it becomes binding. ${ }^{120}$ A selfexecuting agreement, on the other hand, automatically becomes binding law upon ratification.

118. See Bestor, "Advice from the Very Beginning, 'Consent' when the End is Achieved," in Foreign Affairs, supra n. 26, at 6.

119. See Restatement, supra n. 77, § 303 Comments i, j.

120. See Foster v. Neilson, 27 U.S. (2 Pet.) 253 (1829); Whitney v. Robertson, 124 U.S. 190 (1888). 
When a self-executing treaty conflicts with a prior act of Congress, the later in time prevails. ${ }^{121}$ The Supreme Court has held that treaties and legislation have equal constitutional status; both are the supreme law of the land. Consequently, a valid legislative act by Congress can also modify, amend or abrogate a treaty. ${ }^{122}$ However, as a matter of statutory construction, an act of Congress and a valid treaty will be interpreted in such a way as to give them both effect, unless the language of either would be violated and Congress's intent to modify the treaty is clearly expressed.123 If Congress decides to abrogate a treaty, however, the United States remains bound by its treaty obligations, and would be subject to claims for treaty default under international law. ${ }^{124}$

Although the constitution is silent about executive agreements, and says nothing about their supremacy, the courts have held that valid executive agreements are supreme over state laws and policies. In United States $v$. Pink, ${ }^{125}$ a New York state court refused to recognize the United States government's title to New York insurance assets formerly owned by the Russians. President Roosevelt had concluded the Litvinov Assignment by sole executive agreement with the Soviet government, which had the effect of assigning the foreign assets of nationalized Russian insurance businesses to the United States. The Supreme Court held that because the Litvinov Assignment was concluded pursuant to the President's sole power to recognize foreign government, it had the same status as treaties, and therefore prevailed over state policy. New York state's policy against recognition of the Soviet Government and the assignment of property violated the executive agreement, and therefore was invalid in the face of supreme federal law. In Dames \& Moore v. Regan, ${ }^{126}$ the Supreme Court upheld the supremacy of executive agreements over state law when it affirmed the constitutionality of an executive order settling claims against Iranian assets in the United States that had arisen in connection with the Iranian hostage incident. The validity of the agreement was based on the President's power to settle foreign claims, the exercise of which the Congress had long since acquiesced in.

While executive agreements are clearly supreme law in relation to state laws, the status of executive agreements vis-a-vis inconsistent federal law is less clear. In United States v. Guy W. Capps,

\footnotetext{
121. See Whitney v. Robertson, 124 U.S. 190 (1888).

122. See Chae Chan Ping v. United States, 130 U.S. 581 (1889) (Chinese Exclusion Case).

123. See Whitney, 124 U.S. at 194; see also Nowak \& Rotunda, supra n. 22, at 214-

124. See Restatement, supra n. 77, \& 115(1)(b).

125. 315 U.S. 203 (1942).

126. 453 U.S. 654 (1981).
} 15. 
Inc., ${ }^{127}$ the Court of Appeals ruled that an executive agreement was invalid in the face of conflicting federal legislation because the President improperly exercised powers delegated to him by earlier congressional act. While the Supreme Court has not ruled directly on the issue, the Capps case suggests that some executive agreements are not equal in all respects to federal legislation. It is likely, for example, that a sole executive agreement, entered into by the President based on the executive's sole foreign affairs powers, would be supreme over conflicting state law, but not over an inconsistent federal statute.

\section{The War Power}

The vesting of war powers in both the President and Congress has led to conflicts about which branch has the dominant authority. Congress often claims to have the dominant role in the exercise of war powers based on its constitutionally delegated powers to declare war, to make the rules of warfare, and to make all laws necessary and proper to execute the war power. ${ }^{128}$ In addition, Congress bases its claim on its power to tax and finance defense programs, ${ }^{129}$ and to raise and support the armed forces, although appropriations for the armed forces cannot be for a longer term than two years. ${ }^{130}$

In spite of the express vesting of the power to declare war in the Congress, Presidents have often committed United States armed forces in foreign conflicts without a congressional declaration of war, based on the executive power to defend American interests abroad. Growing objections to this presidential exercise of power, especially after the Vietnam War, led the Congress to adopt the War Powers Resolution ${ }^{131}$ over presidential veto in 1973. Section 1 of the War Powers Resolution states that its purpose was

to fulfill the intent of the framers of the Constitution of the United States and insure the collective judgment of both the Congress and the President will apply to the introduction of United States Armed Forces into hostilities, or into situations where imminent involvement in hostilities is clearly indicated by the circumstances, and to the continued use of such forces in hostilities or in such situations. ${ }^{132}$

The term "introduction of United States Armed Forces" is defined to include the assignment of military commanders and planners, and participation in the regular or irregular forces of a foreign govern-

127. 204 F.2d 655 (4th Cir. 1953).

128. U.S. Const. art. I, sec. 8.

129. Id. sec. 8 , cl. 1 .

130. Id. sec. 8, cl. 12 .

131. 50 U.S.C. $\$ \$ 1541-48$ (1973).

132. Id. $\S 1542(a)$. 
ment engaged in hostilities or in circumstances where hostilities are imminent. ${ }^{133}$

The War Powers Resolution purports to subject the presidential commitment of armed forces to congressional control, although it does expressly provide for an exception if the United States is attacked.134 The President is required to report to Congress within forty-eight hours of introducing armed forces into a conflict. ${ }^{135}$ Congress then has sixty days to declare war or extend the sixty day period, otherwise the President must withdraw the armed forces. ${ }^{136}$ Moreover, the Congress retains the authority to direct the President to withdraw troops, even within the sixty-day period, by concurrent resolution of the House and the Senate. ${ }^{137}$

The application of the War Powers Resolution raises a variety of questions. It has been argued that the Resolution improperly infringes upon the President's power as commander-in-chief. Moreover, the provision allowing the Congress to recall United States forces by concurrent resolution without presentation of the resolution for signature by the President may be an unconstitutional legislative veto in light of INS $v$. Chadha. ${ }^{138}$ On the other hand, Justice Jackson's concurrence in The Steel Seizure case suggests that the President's power in this area is at its lowest ebb in the face of congressional action. This dispute may never be judicially resolved, however, because it is the sort of inter-branch struggle subject to the courts' political question doctrine.

In addition to questions regarding the separation of powers in the introduction of troops in foreign conflicts, the proper scope of the war powers has given rise to other tensions between the President and Congress. The Steel Seizure ${ }^{139}$ case provides an example of the struggle between the President and Congress regarding emergency economic powers during war. President Truman had attempted to seize the domestic steel industry by executive order, claiming emergency powers during war based on the President's commander-inchief power and on his general executive powers. The Supreme Court invalidated the order as an unconstitutional exercise of power in the face of contrary congressional legislation. The Court noted that the President's power must stem from either an act of Congress or the Constitution. The President had no statutory authority for seizing the plants; Congress had in fact expressly rejected plant seizure as a method for preventing strikes. Moreover, the action did not fall

133. Id. § 1548(c).

134. Id. \& 1542(c)(3).

135. Id. \& 1544 .

136. Id. $\S 1545(\mathrm{~b})$.

137. Id. \& 1545(c).

138. 462 U.S. 919 (1983).

139. Youngstown Sheet \& Tube Co. v. Sawyer, 343 U.S. 579 (1952). 
within the President's commander-in-chief power. Distinghing cases upholding broad powers for military commanders, the Court held:

Such cases need not concern us here. Even though "theater of war" be an expanding concept, we cannot with faithfulness to our constitutional system hold that the Commander in Chief of the Armed Forces has the ultimate power as such to take possession of private property in order to keep labor disputes from stopping production. This is a job for the Nation's law-makers, not for its military authorities. ${ }^{140}$

In other words, it is the role of Congress to make domestic laws, not the Executive.

In contrast to the President's power over the domestic economy during war, the Congress's power is very broad. The Supreme Court, in Woods v. Cloyd W. Miller Co., ${ }^{141}$ held that Congress's power to regulate war included the power not only to regulate domestic economic affairs during hostilities, such as the imposition of rent control, but the power continues even after hostilities have terminated, or until the emergency has ended.

Another source of conflict over the exercise of the war powers between the President and Congress relates to Congress's "power of the purse." The Constitution expressly provides that Congress has the sole power to appropriate funds from the United States treasury. Moreover, the Congress is expressly vested the power to "raise and support" an army and to provide for and maintain a navy. This separation of the appropriations power was intended to prevent the branch of government responsible for executing the laws from having direct access to the source of funding, and in the case of the armed forces, to separate the commander of the forces from the means to support them independently, thereby giving the Congress an effective check on the expansion of executive power. Congress's supremacy over the purse has been acknowledged by Presidents from the beginning of the republic: both Presidents Jefferson and Jackson in the face of threatened aggression from Spain and by South American pirates, respectively, recognized that Congress had exclusive control over the means necessary to carry out military efforts. President Nixon acknowledged Congress's power over funding for the Vietnam War, even as he continued to step up the prosecution of that war.

The extent to which Congress can control the President through the power of the purse is unclear. There is some evidence that at least some of the founders believed that the President had inherent emergency spending powers, the exercise of which must be affirmed by Congress at the earliest opportunity. Others have suggested that the President, even in the face of a cut-off of funds by the Congress,

140. Id. at 587.

141. 333 U.S. 138 (1948). 
may continue an operation with funds already appropriated. However, this question has never been specifically answered. ${ }^{142}$ Even during the Iran-contra affair, while some of President Reagan's staff believed the Boland Amendment, which cut off all funding for the Nicaraguan contras, was an unconstitutional infringement of the President's foreign affairs powers, the crisis only involved the use of funds independently raised from the sale of arms to Iran rather than funds appropriated by Congress.

United Nations enforcement action, adopted pursuant to a resolution of the United Nations Security Council, might also serve as a source of tension between the President and Congress over the proper exercise of the war power. The question is whether the President has the power to commit United States armed forces to an international police action pursuant to a Security Council resolution without first seeking a Congressional declaration of war. ${ }^{143}$ One theory on which such a power might be based is that in giving consent to the United Nations Charter, the Senate impliedly consented to any future enforcement action. However, given that agreements between the United Nations and the United States regarding the provision of military forces pursuant to United Nations Charter Article 43, which would require Senate consent, have never been negotiated, this theory appears unpersuasive. Furthermore, actual practice during the Iraq-Kuwait War, where President Bush sought congressional approval before committing troops to actual hostilities, suggests that the President, in the absence of a prior agreement negotiated between the United States and the United Nations and confirmed by the Senate, should seek congressional approval before prosecuting an international enforcement action.

\section{The Role of the Judiciary in Foreign Affairs}

\section{A. The Place of the Judiciary within the Constitutional System of Government of the United States}

The judicial power of the federal government of the United States is vested in the United States Supreme Court and the other lower federal courts established by act of Congress. ${ }^{144}$ The constitutional role of the Supreme Court in the federal system is set out in Article III of the Constitution:

The judicial Power shall extend to all Cases, . . . arising under this Constitution, the Laws of the United States, and Treaties made, or which shall be made, under their Author-

142. See generally the materials set out in Franck \& Glennon, supra n. 26, at 66384.

143. See Stromseth, supra n. 91; Glennon, supra n. 29.

144. U.S. Const. art. III, sec. 1. 
ity;- to all Cases affecting Ambassadors, other public Ministers and Consuls;-- to all Cases of admiralty and maritime jurisdiction;- to Controversies to which the United States shall be a Party;-to Controversies between two or more States;--between a State and Citizens of another State;--between Citizens of different States; ... and between a State, or the Citizens thereof, and foreign States, Citizens, or Subjects.

In all Cases affecting Ambassadors, other public Ministers and Consuls, and those in which a State shall be a Party, the supreme Court shall have original Jurisdiction. In all other Cases before mentioned, the supreme Court shall have appellate Jurisdiction, both as to Law and Fact, with such Exceptions, and under such Regulations as the Congress shall make. ${ }^{145}$

Although the Constitution is silent about the availability of judicial review by the Supreme Court of acts of the other branches of the federal government, judicial review of acts of state or local governments, and the scope of such review, it has been firmly established as a matter of constitutional law that the Supreme Court has the power to review the acts of the other organs of government in the United States, and declare those acts unconstitutional. As a result; the Supreme Court and the lower federal courts, through the exercise of judicial review, have contributed to the evolving nature of the Constitution. By interpreting and applying the Constitution to "cases or controversies," the federal courts have given meaning to the often broad language of constitutional provisions, and developed constitutional doctrines to deal with the problems that confronted a growing and expanding nation. Through the power of judicial review, constitutional provisions and doctrines have been adapted and modified to address issues that never could have been foreseen by the framers, keeping the Constitution a vital and "living" document right up to the present day.

The power of judicial review of the other branches of the federal government was established by Chief Justice John Marshall in the landmark case of Marbury $v$. Madison. ${ }^{146}$ At the end of the Eighteenth Century, growing discontent with the federal government dominated by the Federalist Party led to the defeat of the Federalist President John Adams, and the election of the third President, Thomas Jefferson, an anti-federalist and the founder of the Democratic-Republican Party (now called the Democratic Party). In the waning hours of President Adams's term, in an attempt to pack the federal government with other Federalists, President Adams made a

145. Id. sec. 2, cl. 1-2.

146. 5 U.S. (1 Cranch) 137 (1803). 
series of "midnight" appointments. Among them was the appointment of John Marshall to be the fourth Chief Justice of the Supreme Court, and the appointment of Federalists to newly-created circuit court judgeships. The final act of the Adams administration was to appoint several justices of the peace to serve five-year terms in the District of Columbia and Alexandria. However, some of the commissions were never actually delivered to the individuals appointed while Adams was still in office, and once Thomas Jefferson assumed the Presidency, he refused to deliver them.

One such individual, William Marbury, brought suit against the new Secretary of State, James Madison, in the Supreme Court to compel delivery of his commission. Chief Justice Marshall used the case as a vehicle to assert the Court's power to review the acts of the other branches of the federal government. After finding that Marbury had a vested right to the commission, Justice Marshall turned first to the question of whether the law provided Marbury with a remedy. Justice Marshall maintained that it is the "essence of civil liberty" that a legal remedy be available for a legal wrong. Since the government of the United States is one of "laws and not of men," it must grant a remedy for legal wrongs. ${ }^{147} \mathrm{He}$ conceded that some acts, which are political in nature, or left to the discretion of the Executive, are only politically reviewable, and not subject to judicial review. However, if the Executive is assigned a specific duty by law, it cannot disregard such a duty. In this case, the President was under a legal duty to deliver the commissions. Therefore, Marbury was entitled to a remedy under the law.

After finding that Marbury was entitled to a remedy, Marshall noted that the Judiciary Act of 1789 provided him with one, namely a writ of mandamus. Justice Marshall then turned to the question of whether the Constitution allowed the Supreme Court to issue the writ. In the key part of the decision, Justice Marshall found that a writ of mandamus can only be issued from a court with original jurisdiction. Because the Constitution only provides for original jurisdiction in cases affecting ambassadors, ministers and consuls, and in cases in which a state is a party, the Supreme Court could not issue the writ in this case, which involved a justice of the peace. Therefore, the Judiciary Act, which provided the remedy, was in conflict with the Constitution.

To resolve the conflict, Justice Marshall held that a legislative act contrary to the Constitution was not a law. His reasoning was deceptively simple: The people of the United States established a government of limited powers by adopting the Constitution. The limitations on government incorporated in the written Constitution would be lost if the Constitution does not control unconstitutional acts.

147. Id. at 163 . 
Therefore, the Constitution is superior to inconsistent acts of Congress, and unconstitutional acts are invalid.

Justice Marshall then went one step further to hold that "it is emphatically the province and duty of the judicial department to say what the law is."148 An inability to reject laws in favor of the Constitution would subvert the very nature of a written constitution. Therefore, if the Court is given the choice between the Constitution and an inconsistent act of Congress, it is the Court's duty to apply the Constitution, and strike down the act of Congress as unconstitutional.

Through this logic, Justice Marshall established the role of the Supreme Court as the final arbiter of constitutional interpretation, and laid the cornerstone for judicial review of acts of the Executive and Congress which survives to this day. Indeed, much of Justice Marshall's reasoning is subject to criticism. ${ }^{149}$ President Jefferson himself disagreed with the Court, but because the case ultimately went in his favor - Marbury being denied the writ of mandamus the case went unchallenged. The decision in Marbury is considered to be Justice Marshall's "master stroke" - by giving the new President what he wanted, Justice Marshall was able to assert an important power for the Court, and thereby establish a key role for the Court in the constitutional system of government.

In a series of early cases, the Supreme Court also established its power to review the acts of state and local governments. One such case, Martin $v$. Hunter's Lessee, ${ }^{150}$ involved a conflict between a treaty and a state law. Hunter claimed title to land in northern Virginia pursuant to a grant by the state. Virginia had earlier passed an act confiscating the land of individuals who were British citizens or loyalists during the Revolutionary War. Martin, a British citizen who inherited the land from his uncle Lord Fairfax, a British subject who had become a citizen of Virginia before he died, claimed title to the same land pursuant to a treaty between the United States and Great Britain. Martin lost his case in the Virginia Court of Appeals, and appealed to the United States Supreme Court. Because the Constitution makes treaties supreme law over state law, the Supreme Court remanded the case to the Virginia court with orders to enter judgment for Martin. The Virginia court refused, denying that the federal court had the power to order a state court.

On appeal, the United States Supreme Court ruled that it had the power to review state court actions. In an opinion by Justice Story (Chief Justice Marshall had recused himself from the case due to his involvement as Secretary of State in negotiating the treaty and

148. Id. at 177.

149. See e.g., Nowak \& Rotunda, supra n. 22, at 6-10.

150. 14 U.S. (1 Wheat) 304 (1816). 
his ownership of land that might be affected by the decision), the Court ruled that the Constitution gave the Court jurisdiction over all cases arising under the Constitution, federal statutes, and treaties, and this jurisdiction included appellate review of state court cases. Because the Supremacy Clause makes treaties the supreme law of the land, state court judges are bound to apply them. Because the Supreme Court is the final arbiter of the meaning of the federal constitution, statutes, and treaties, state courts are bound by its rulings, thereby ensuring the uniformity of federal law.

The long-term significance of judicial review cannot be overemphasized. It has provided the federal courts with a key role in enforcing limits on the political branches of government and protecting individual rights in the face of majoritarian excesses. In the latter part of the Nineteenth Century, the courts used the power of judicial review to strike down economic regulations that impaired the "liberty of contract." In the Twentieth Century, the courts retreated from their enforcement of economic rights, focusing instead on important individual liberties such as the freedom of speech and the press, the right to due process of law, and the right of equal protection of the law. As noted by Alexis de Tocqueville, almost every political and social issue is eventually litigated in the United States. ${ }^{151}$ Judicial review makes this possible, with the courts often serving as the last refuge for people unable to secure their rights through the political processes, whether federal, state or local. As a result, the Supreme Court has often been at the center of important social movements, as exemplified by the Civil Rights cases of the 1950s and 1960s, and the battle over abortion rights today.

The availability of judicial review helps to ensure the pervasiveness of the rule of law in the United States. It has often been said that in the United States, no one is above the law. The use of the courts by individuals challenging the acts of presidents and the government has contributed to the reality of this principle.

The willingness of the federal courts to review the acts of other organs of American government in the domestic realm, is tempered somewhat in the realm of foreign affairs. The courts have been hesitant to exercise judicial review in cases involving the President's and Congress's foreign affairs powers for reasons that will be discussed in more detail below. However, judicial review is still available in the foreign affairs arena, and the courts have occasionally exercised that power to resolve important disputes.

151. Alexis de Tocqueville, Democracy in America 99-105 (G. Lawrence, trans., J. Mayer ed. 1969). 


\section{B. The Doctrine of Political Questions (Non-Justiciability)}

Despite the broad scope of the power of judicial review, there are some limits on its exercise. Some limits are constitutional, including standing, ${ }^{152}$ ripeness, ${ }^{153}$ and mootness. ${ }^{154}$ Moreover, the courts are constitutionally prevented from issuing advisory opinions. 155

There are also jurisprudential, or judge-made, limits on judicial review. The most significant of these in the foreign affairs area is the doctrine of political questions. The term "political question" has been used in two quite different contexts. In the first, the court makes a finding that the question before it has been constitutionally allocated to another branch of government, applies the appropriate standard, and generally finds the action constitutional. In this sense, the court does not actually hold that the case is non-justiciable; rather, it defers to the other coordinate branch of government. In the second context, the court will actually hold that a case is non-justiciable, or incapable of judicial resolution. This sense of the political question doctrine is invoked when obtainable evidence is lacking, when the court finds it difficult to craft manageable standards, or out of judicial prudence.

In the case of Baker $v$. Carr, ${ }^{156}$ Justice Brennan gave a definition of when a case involves a political question:

Prominent on the surface of any case held to involve a political question is found a textually demonstrable constitutional commitment of the issue to a coordinate political department; or a lack of judicially discoverable and manageable standards for resolving it; . . . or the potentiality of embarrassment from multifarious pronouncements by various departments on one question. ${ }^{157}$

152. Chief Justice Warren described the standing doctrine as being a question of whether the person whose standing is challenged is a proper party to request the adjudication of a particular issue and not whether the issue itself is justiciable ... the emphasis ... is on whether the party invoking federal court jurisdiction 'has a personal stake in the outcome of the controversy' and whether the dispute touches upon 'legal relations of parties having adverse legal interests.'

Flast v. Cohen, 392 U.S. 83, 99-101 (1968). See also Monaghan, "Constitutional Adjudication: The Who and When," 82 Yale L.J. 1363 (1973).

153. The ripeness doctrine prevents the courts from hearing cases prior to the existence of a fully-developed case or controversy worthy of judicial review. See Roe v. Wade, 410 U.S. 113, 127-29 (1973); Abbott Laboratories v. Gardner, 387 U.S. 136 (1967); United Public Workers v. Mitchell, 330 U.S. 75 (1947).

154. The mootness doctrine requires that a genuince controversy remain "alive" from the time the complaint is filed until its final disposition by the Supreme Court. See Defunis v. Odegaard, 416 U.S. 312 (1974). See also "Note, The Mootness Doctrine in the Supreme Court," 88 Harv. L. Rev. 373 (1974).

155. See Nowak \& Rotunda, supra n. 22 , at 54-58.

156. 369 U.S. 186 (1962), on remand 206 F. Supp. 341 (M.D. Tenn. 1962).

157. Id. at 217. 
Justice Brennan noted that the area of foreign affairs often fits within the political question doctrine because the issues involve standards that defy judicial application, the exercise of discretion committed to the executive or legislative branch, or questions that require the single-voiced statement of the government. However, Justice Brennan also noted that the political question doctrine will not prevent judicial review when the executive and legislative branches have failed to act.

The political question doctrine has been invoked by the courts to avoid ruling on questions regarding the conduct of foreign relations, or the making and conduct of hostilities. ${ }^{158}$ In spite of these cases, no good definition of when a case presents a political question has been formulated, and there is debate over what a political question really is. Moreover, while the doctrine is available, the courts, perhaps in an attempt to maintain independence from the other branches, rarely invoke the doctrine to abstain from deciding foreign affairs cases, preferring instead to review the actions of the executive and legislative branches and to find that they acted within their constitutional powers. ${ }^{159}$

\section{Judicial Review Regarding Foreign Affairs in General}

While the Constitution vests the bulk of foreign affairs powers in the executive and legislative branches of the federal government, it also provides for a significant and important role for the judicial branch. The constitutional grant of jurisdiction to the federal courts includes the power over cases arising under treaties, cases affecting ambassadors, cases to which the United States is a party, and cases between United States citizens and foreign states.

These provisions have served as the basis for the Supreme Court's exercise of jurisdiction over cases involving foreign nations, suits by United States citizens against foreign nationals and diplomats, and cases involving the interpretation and application of treaty provisions. In addition, the Court's power to review cases arising under the laws of the United States provides a basis for reviewing domestic legislation implementing treaty obligations.

Through the power of judicial review, the Supreme Court has established its jurisdiction over issues arising from the application of international agreements other than treaties. In B. Altman \& Co. v. United States, ${ }^{160}$ the Supreme Court held that it had jurisdiction to

158. See infra Sec. VI.G.

159. For a criticism of the political question doctine in the context of foreign affairs disputes, see Charney, "Judicial Deference in Foreign Relations," in Foreign Affairs, supra n. 26, at 98; Glennon, "Foreign Affairs and the Political Question Doctrine," in id. at 107; Henkin, “Is There a 'Political Question' Doctrine?," 85 Yale L.J. 597 (1976). 160. 224 U.S. 583 (1912). 
review an appeal regarding a congressional-executive agreement. In construing the Judiciary Act of 1891, which provided for the direct appeal of a lower federal court judgment to the Supreme Court in "any case in which the constitutionality of any law of the United States or the validity or construction of any treaty made under its authority is drawn into question," the Court reasoned that a congressional-executive agreement, although not technically a treaty subject to formal Senate ratification, was nevertheless the type of "international compact, negotiated between representatives of two sovereign nations and made in the name and on the behalf of the contracting countries" that Congress intended to include in the Act. And while the $B$. Altman case involved a congressional-executive agreement, its logic would apparently apply to sole executive agreements as well.

It is also well established that the federal courts have jurisdiction over cases arising under customary international law. In the $\mathrm{Pa}$ quete Habana, ${ }^{161}$ the Supreme Court held:

International law is part of our law, and must be ascertained and administered by the courts of justice of appropriate jurisdiction, as often as questions of right depending upon it are duly presented for their determination.

Moreover, it has been suggested that the constitutional authority of the Congress to define and punish international law violations impliedly incorporates international law into United States law. ${ }^{162} \mathrm{Be}-$ cause the courts have jurisdiction over cases arising under United States law, their jurisdiction therefore includes the power to ascertain and apply international law.

Exercising the power of judicial review over cases involving treaties, other international agreements, and customary international law, the courts have established a variety of rules regarding the status, determination and interpretation of international law and agreements. In general, international law and agreements are federal law. As a consequence, the Supreme Court, as the final arbiter of United States law, has conclusive authority to determine and interpret international law for all courts in the United States, whether federal or state. The need for national uniformity in the application of international law also suggests that state courts should follow the rulings of lower federal courts as a matter of deference. The determination and interpretation of the content of international law or agreements is a question of law and subject to judicial notice without any special pleading or proof requirements. ${ }^{163}$ However, judges often rely on expert witnesses and other relevant evidence to aid in determining the content of customary international law.

161. 175 U.S. 677 (1900).

162. See U.S. Const. art. I, sec. 8, cl. 10.

163. See Paquete Habana, 175 U.S. at 708. 
As a matter of construction, courts attempt to avoid interpreting federal statutes in such a way as to conflict with international law or agreements. Chief Justice Marshall noted that "an Act of Congress ought never to be construed to violate the law of nations if any other possible construction remains." 164 In numerous cases, the Court has applied this principle to avoid conflicts between federal statutes and earlier treaty provisions. When there is a conflict between an international agreement and a federal statute, the courts have crafted a variety of doctrines to help resolve such conflicts, such as the Last in Time Doctrine. ${ }^{165}$ Judicial resolution of conflicts between federal law and customary international law is discussed below. ${ }^{166}$

\section{Judicial Review of Matters Involving the Formation, Interpretation, and Application of International Agreements}

Other than constitutional limitations, or limitations imposed by international law, there are no limits to the subject matter of treaties or international agreements, and the courts have not imposed any such limits of their own. At one time it was suggested that the United States can only enter into treaties dealing with matters of "international concern." 167 This view, however, has been rejected, and the Supreme Court has upheld the validity of treaties concluded on a variety of "domestic" subjects, such as the rights of inheritance in land ${ }^{168}$ or the regulation of migratory birds. ${ }^{169}$ Apparently, the only requirement for the formation of a valid treaty is that it must be a bona fide international act entered into with one or more foreign powers, although the Supreme Court has never invalidated a treaty on these grounds. 170

In the interpretation of treaties and other international agreements, the judicial branch gives "great weight" to initial interpretations by the Executive. ${ }^{171}$ But because treaties and international agreements are part of United States law, and the Supreme Court is the final arbiter of United States law, the Supreme Court has the final authority to interpret international agreements. The Court has held that treaty interpretation is not a political question, and gener-

164. Murray v. Schooner Charming Betsy, 6 U.S. (2 Cranch) 64 (1804).

165. See supra Sec. V.B.

166. See infra Sec. VI.F.

167. See Statement by Charles Evans Hughes, 23 Proc. Am. Soc'y Int'l L. 194-96 (1929).

168. Geofroy v. Riggs, 133 U.S. 258 (1890).

169. Missouri v. Holland, 252 U.S. 416 (1920).

170. See Restatement, supra n. 77, $\S 302$ Rep. Notes 2.

171. See, e.g., Kolovrat v. Oregon, 366 U.S. 187 (1961); Zschernig v. Miller, 389 U.S. 429 (1968). 
ally, the courts will not decline to hear such cases. ${ }^{172}$ Consequently, the courts employ a variety of tools in treaty interpretation to ascertain the meaning of treaty provisions including interpretation of the plain meaning of treaty terms, recourse to travaux préparatoires, and analysis of relevant congressional materials developed during treaty ratification. Moreover, because customary international law is federal law, the international rules of treaty interpretation, to the extent that they have become binding customary law, would also be binding on United States courts. ${ }^{173}$

International agreements duly concluded by the federal government are capable of application in United States courts, and can be the source of individual rights and remedies in individual cases. The Supremacy Clause of the Constitution provides that treaties are the supreme law of the land.174 In theory, treaties negotiated by the President, consented to by two-thirds of the Senate, and subsequently ratified by the President are equivalent to other federal laws, and are capable of direct application by federal and state courts without any further congressional action. The Supreme Court has determined, however, that neither all treaties, nor all treaty provisions, automatically have such legally binding authority. The courts make a distinction between self-executing treaties or treaty provisions, which are automatically capable of application in the courts, and nonself-executing treaties or treaty provisions, which require an additional act of Congress before they can be enforced in the courts.

The distinction between self-executing and non-self-executing agreements was recognized early on by Chief Justice John Marshall. In the case of Foster $v$. Neilson, ${ }^{175}$ Justice Marshall wrote:

Our constitution declares a treaty to be the law of the land. It is, consequently, to be regarded in courts of justice as equivalent to an act of the legislature, wherever it operates of itself, without the aid of any legislative provision. But when the terms of the stipulation import a contract, when either of the parties engages to perform a particular act, the treaty addresses itself to the political, not the judicial department; and the legislature must execute the contract, before it can become a rule for the court. ${ }^{176}$

Likewise, in The Head Money Cases, 177 the Supreme Court held:

172. Similarly, the Court has held that the interpretation of statutes, even if they involve foreign affairs, are not political questions, and are therefore justiciable. See Japan Whaling Ass'n v. American Cetacean Soc'y, 478 U.S. 221 (1986).

173. See Restatement, supra n. 77, § 325 and Comments.

174. See U.S. Const. art. VI.

175. 27 U.S. (2 Pet.) 253 (1828).

176. Id. at 314.

177. 112 U.S. 580 (1884). 
A treaty is primarily a compact between independent nations. It depends for the enforcement of its provisions on the interest and the honor of the governments which are parties to it ... . But a treaty may also contain provisions which confer rights upon the citizens or subjects of one of the nations residing in the territorial limits of the other, which partake of the nature of municipal law, and which are capable of enforcement as between private parties in the courts of the country . . . A treaty, then, is a law of the land as an act of Congress is, whenever its provisions prescribe a rule by which the rights of the private citizen or subject may be determined. ${ }^{178}$

Whether an international agreement is self-executing depends, generally, on the intent of the parties as determined from the treaty provision itself. If the treaty is uncertain, then the courts determine intent by considering a variety of factors, including:

(1) the language and purposes of the agreement as a whole;

(2) the circumstances surrounding its execution; (3) the nature of the obligations imposed by the agreement; (4) the availability and feasibility of alternative enforcement mechanisms; (5) the implications of permitting a private cause of action; and (6) the capability of the judiciary to resolve the dispute. ${ }^{179}$

Applying these principles, the courts have held a variety of international agreements to be self-executing. The most common self-executing treaties include treaties of friendship, commerce, and navigation, and agreements conferring rights on foreign nationals, such as treaties protecting foreign creditors from cancellations of their debts, ${ }^{180}$ treaties ensuring inheritance rights, ${ }^{181}$ and extradition treaties. ${ }^{182}$ In contrast, international agreements in the human rights area have been held to be non-self-executing. The United States Court of Appeals for the Seventh Circuit, for example, held that the human rights provisions of the Helsinki Accords are not selfexecuting because the provisions of the treaty "contemplate further action by the participating states" to carry them out. ${ }^{183}$ Similarly, the 1967 United Nations Protocol Relating to the Status of Refu-

178. Id. at 598-99.

179. Frolova v. Union of Soviet Socialist Republics, 761 F.2d 370, 373 (7th Cir. 1985), citing Tel-Oren v. Libyan Arab Republic, 726 F.2d 774 (D.C. Cir. 1984) (Bork, J., concurring), cert. denied, 470 U.S. 1003 (1985); United States v. Postal, 589 F.2d 862 (5th Cir.), cert. denied, 444 U.S. 832 (1979); People of Saipan v. United States Dep't of Interior, 502 F.2d 90 (9th Cir. 1974), cert. denied, 420 U.S. 1003 (1975); Sei Fujii v. State, 242 P.2d 617 (1952).

180. See Ware v. Hylton, 3 U.S. (3 Dall.) 199 (1796).

181. See, e.g., Kolovrat v. Oregon, 366 U.S. 187 (1961).

182. See, e.g., United States v. Rauscher, 119 U.S. 407 (1886).

183. Frolova, 761 F.2d at 375-76. 
gees, ${ }^{184}$ and the Universal Declaration of Human Rights, as an international agreement, are considered non-self-executing. ${ }^{185}$ The human rights provisions of the United Nations Charter have also been declared non-self-executing, ${ }^{186}$ although the Charter provisions requiring compliance with United Nations Security Council resolution have been held to be self-executing. ${ }^{187}$

The power to terminate treaties and international agreements is not provided for in the Constitution. Consequently, the courts, exercising judicial review, could in theory settle the issue. However, there is no authoritative ruling on the subject. The closest the Supreme Court has come to ruling on each branch's power to terminate treaties came in the case of Goldwater $v$. Carter. ${ }^{188}$ In this case, a number of Senators and House Representatives challenged President Carter's plan to terminate a mutual defense treaty with Taiwan, and recognize the People's Republic of China as the government of China. The Supreme Court, without opinion, ordered a lower federal court to dismiss the case. A statement concurred in by four justices declared the controversy to be a non-justiciable political question because it involved the President's authority in the conduct of foreign affairs and the extent to which Congress could check presidential action. Justice Brennan, on the other hand, while rejecting the majority's interpretation of the political question doctrine, indicated he would not review the decision to terminate the treaty because it rested on the President's sole power to recognize foreign governments.

Only Justice Powell rejected the political question doctrine entirely in this case. He concurred in the judgment because he believed the question was not yet ripe (Congress had not adopted legislation contrary to the President's decision). He suggested, however, that if Congress did adopt a conflicting resolution, the Court could settle the conflict by exercising its power to interpret the Constitution. To date, no such action has taken place, and there are no further judicial rulings on treaty termination.

\section{E. Judicial Review of So-Called "Unconstitutional" Treaties and International Agreements}

When exercising its power of judicial review, the judicial branch of the federal government has often employed the first ten amendments to the United States Constitution, also known as the Bill of Rights, as a limit on the power of the executive and legislative

184. See Bertrand v. Sava, 684 F.2d 204 (2d Cir. 1982).

185. See Haitian Refugee Center, Inc. v. Gracey, 600 F. Supp. 1396 (D.D.C. 1985) citing In re Alien Children Education Litigation, 501 F. Supp. 544 (S.D. Tex. 1980).

186. See, e.g., Frolova, 761 F.2d at 373-75.

187. See United States v. Steinberg, 478 F. Supp. 29 (N.D. Ill. 1979).

188. 444 U.S. 997 (1979). 
branches. The constitutional scheme assures that the federal government will be subject to the will of the majority of its citizens by providing for direct election of legislators, both Representatives and Senators, and the President and the Vice-President. ${ }^{189}$ In recognition, however, that abuse of power by a majority can lead to the "tyranny of the majority," the Bill of Rights guarantees individual rights by denying certain powers to the federal government. While the federal court system has often been criticized as being an anti-democratic institution (judges in the federal court system are appointed for life by the President; they are not elected, and can only be removed by impeachment ${ }^{190}$ ), the relative independence of federal judges from the political process has often placed them in a unique position to uphold and enforce the Bill of Rights as a limit, thereby protecting the human rights of minorities against power abuses by the majority.

The Bill of Rights is no less a limitation on the power of the federal government in the foreign affairs realm than it is in the domestic. Consequently, while the treaty power is generally construed to be very broad, its exercise is still subject to the constitutional limits of the Bill of Rights and other constitutional constraints. As Justice Field stated in his famous dicta in Geofroy v. Riggs: ${ }^{191}$

That the treaty power of the United States extends to all proper subjects of negotiation between our government and the governments of other nations, is clear .... The treaty power, as expressed in the Constitution, is in terms unlimited except by those restraints which are found in that instrument against the action of the government or of its departments .... It would not be extended so far as to authorize what the Constitution forbids, or a change in the character of the government or in that of one of the States, or a cession of any portion of the territory of the latter, without its consent . . . B But with these exceptions, it is not perceived that there is any limit to the questions which can be adjusted touching any matter which is properly the subject of negotiation with a foreign country. ${ }^{192}$

Consequently, the Bill of Rights and other constitutional provisions limit the exercise of the treaty power just as they limit any other constitutional exercise of power by the branches and departments of the federal government.

The principle that the first eight amendments of the Bill of Rights, which protect certain individual rights such as freedom of

189. See U.S. Const. art. I, sec. 2 , art. II, sec. 1; id. amends. XII, XVII.

190. See id. art. II, sec. 2 , cl. 2 , art. III, sec. 1.

191. 133 U.S. 258 (1890).

192. Id. at 266-67. 
speech and religion, ${ }^{193}$ right against unreasonable searches and seizures, ${ }^{194}$ the right to due process of law and just compensation for the public taking of private property, ${ }^{195}$ and the right to a jury trial,196 act to limit the treaty power was established in the case of Reid v. Covert. ${ }^{197}$ In Reid, two women married to military husbands were charged with the murder of their husbands while stationed abroad. Even though the women were civilians, they were subjected to military court-martial, without the right to trial constitutionally guaranteed civilians, as permitted by executive agreements entered into by the United States, Japan and Great Britain. The Supreme Court held that the executive agreements providing for the jurisdiction of military courts over civilians was unconstitutional. First, it found that the Necessary and Proper Clause did not allow Congress to subject persons other than members of the "land and naval Forces" to military jurisdiction, as provided in the Constitution, ${ }^{198}$ and that no treaty or agreement could confer powers on the Executive or Congress that they did not possess under the Constitution. Second, the Court ruled that the right to a trial by jury was a vital barrier to governmental arbitrariness, and could not be abrogated by treaty or agreement. The Court reasoned:

When the Government reaches out to punish a citizen who is abroad, the shield which the Bill of Rights and other parts of the Constitution provide to protect his life and liberty should not be stripped away just because he happens to be in another land. ${ }^{199}$

Therefore, the Court ruled that the executive agreements contradicted the Constitution, and the military tribunal could not have jurisdiction over the women. Instead, the women were to be given civil trials accompanied by full constitutional protections.

While constitutional guarantees of individual rights and other provisions of the Constitution limit the treaty power, the Tenth Amendment, which provides that powers not delegated to the United States are reserved to the States, does not. At one time, the argument was made that the Tenth Amendment served as an independent limit on the treaty making power of the federal government. This argument was rejected, however, in the case of Missouri v. $\mathrm{Hol}$ land. ${ }^{200}$ Congress had enacted a statute to protect migratory birds in danger of extinction, which was held invalid by a district court. The

193. U.S. Const. amend. I.

194. Id. amend. IV.

195. Id. amend. V.

196. Id. amends. VI, VII.

197. 354 U.S. 1 (1957).

198. See U.S. Const. art. I, sec. 8, cl. 14.

199. 354 U.S. at 6.

200. 252 U.S. 416 (1920). 
court reasoned that there was no constitutional provision authorizing Congress to regulate in this area (the case was decided at a time when the Commerce Clause was still being construed narrowly). Subsequently, the United States and Great Britain entered into a treaty protecting migratory birds, and Congress adopted legislation similar to the earlier migratory bird statute to implement the treaty.

In a case challenging the new statute on the grounds that the treaty and the new statute violated state's rights protected by the Tenth Amendment, the Court ruled that there was no constitutional violation. According to Justice Oliver Wendell Holmes,

An earlier act of Congress that attempted by itself and not in pursuance of a treaty to regulate the killing of migratory birds within the States had been held bad in the District Court. ... Acts of Congress are the supreme law of the land only when made in pursuance of the Constitution, while treaties are declared to be so when made under the authority of the United States. It is open to question whether the authority of the United States means more than the formal acts prescribed to make the convention. We do not mean to imply that there are no qualifications to the treaty-making power; but they must be ascertained in a different way. It is obvious that there may be matters of the sharpest exigency for the national well being that an act of Congress could not deal with but that a treaty followed by such an act could $\ldots$. $^{201}$

In other words, in the domestic realm, the Tenth Amendment would prevent the federal government from exercising powers not delegated to it in the Constitution. Because the earlier migratory bird statute did not implement any federal power, it was invalid. The treaty power, on the other hand, is expressly delegated to the federal government, and the Tenth Amendment does not limit delegated powers. The later legislation implemented a federal power, namely the treaty power. Because it did not violate the Bill of Rights, or any constitutional provision limiting acts of Congress, it was a constitutional exercise of congressional power. Consequently, so long as a treaty does not confer on Congress the power to act in a manner inconsistent with any specific provision of the Constitution, it may enlarge the scope of Congress's affirmative authority.

In the 1950s, some individuals became concerned that the treaty making power might serve as a tool for ceding sovereignty and undermining democracy in the United States. The fear was based on Justice Holmes's dictum in Missouri v. Holland, stating that the treaty power is not subject to constitutional limitation, combined with the

201. Id. at $432-33$. 
possibility of self-executing treaties. Concern was heightened with the post-World War II international practice of concluding multilateral treaties with considerable law making importance, such as the 1948 Genocide Convention. ${ }^{202}$

In an attempt to "prohibit the use of the treaty as an instrument of domestic legislation," and to "prevent its use as a vehicle for surrendering national sovereignty," Senator Bricker proposed a constitutional amendment, known as the Bricker Amendment, to "plug" the "loophole" of Missouri v. Holland and place limits on the treaty making power. ${ }^{203}$ Although the proposed amendment changed over the years of debate, its provisions typically provided that all treaties would be non-self-executing, and limited the subject matter of treaties to those Congress could enact under its delegated powers in the absence of a treaty. The Bricker Amendment was ultimately rejected by Congress in a vote of 60 for and 31 against (one vote short of the two-third majority required for Congress to propose a constitutional amendment). ${ }^{204}$ With the subsequent ruling in Reid $v$. Covert, concern over the treaty power waned, and no new attempts to limit it by constitutional amendment have been proposed.

\section{F. Judicial Determination of the Place of International Law within the American Constitutional System}

As mentioned above, customary international law is also considered to be part of United States law, and it will be applied by the courts whenever cases raise issues under international law. The status of customary international law as United States law was affirmed by Justice Gray when he stated, "International law is part of our law, and must be ascertained and administered by the courts of justice of appropriate jurisdiction, as often as questions of right depending upon it are duly presented for their determination."205

While customary international law has the status of federal law, it does not have the constitutional status of supreme law, a status expressly granted treaties and statutes under the Supremacy Clause. Instead, customary international law is considered part of United States common law, and is applicable only in circumstances when the application of common law is appropriate. Consequently, customary international law will be applied only in the absence of a federal statute or an international agreement. Because customary international law is deemed not the supreme law of the United States, the Last In

202. Convention on the Prevention and Punishment of the Crime of Genocide, Dec. 9, 1948, 78 U.N.T.S. 277 (entered into force Jan. 12, 1951).

203. See Treaties and Executive Agreements: Hearings Before a Subcommittee of the Senate Committee on the Judiciary on S.J. 130, 82d Cong., 2d Sess. 21 (1953);

Hearings on S.J. Res. 1, 84th Cong., 1st Sess. 19 (1956).

204. See U.S. Const. art. V.

205. Paquete Habana, 175 U.S. 677 (1900). 
Time Doctrine does not apply, as it does to treaties, and, internally and theoretically, an international custom can be abrogated by a Congressional act, whether adopted before or after the custom crystallized as law. ${ }^{206}$

Despite the incorporation of the law of nations into federal common law, the courts have used customary international law only sparingly. Nevertheless, the courts will use the law of nations when there is no corresponding domestic law to apply. The areas in which customary international law has been effectively enforced in the courts include the protection of human rights, ${ }^{207}$ the protection of diplomats, the punishment of piracy and terrorism, the punishment of war crimes, and the settlement of claims arising from the seizure of alien property without just compensation. 208

The use of international human rights law in United States courts is illustrated by the case of Filartiga v. Pena-Irala. ${ }^{209}$ The plaintiffs, Dr. Filartiga and his daughter, both citizens of Paraguay living in the United States, brought suit against another former Paraguayan government official, Pena-Irala, who was also living in the United States, for the torture and murder in Paraguay of Dr. Filartiga's seventeen-year-old son, Joelito. The case was brought pursuant to the Alien Torts Statute, a provision of the Judiciary Act of 1789, which provides: "The district court shall have original jurisdiction of any civil action by an alien for a tort only, committed in violation of the law of nations or a treaty of the United States."210

In addressing the jurisdictional question of whether the conduct of Pena-Irala violated the law of nations, the Second Circuit Court of Appeals found that it did. The Court ruled that "the universal condemnation of torture in numerous international agreements, and the renunciation of torture as an instrument of official policy by virtually all of the nations of the world" established that the act of torture committed by a state official against a person held in detention violated "an established norm of international law of human rights, and hence the law of nations." Among the documents surveyed for evidence of international custom, the Court relied on provisions of the Universal Declaration of Human Rights, ${ }^{211}$ and the American Convention on Human Rights. ${ }^{212}$ The Court then went on to find that international law protected not only aliens from torture, but also protected citizens from their own government. Therefore, as the alleged act of torture

206. See L. Littlejohn \& Co. v. United States, 270 U.S. 215 (1926).

207. See Lillich, "The Constitution and International Human Rights," in Foreign Affairs, supra n. 26 , at 145 .

208. See generally materials set out in Franck \& Glennon, supra n. 26, at 122-226.

209. 630 F.2d 876 (2d Cir. 1980).

210. 28 U.S.C. \& $1350(1988)$.

211. U.N.G.A. Res. 217 A (III), U.N. Doc. A/810 (1948).

212. O.A.S. Treaty Series No. 36 , O.A.S. Off. Rec. OEA/Ser. 4 V/II 23, doc. 21 , rev. 2 (English ed., 1975). 
was a violation of a fundamental international human right, the Court had jurisdiction over the case as provided by the Alien Tort Statute.

\section{G. Judicial Review Regarding the Making and Conduct of War}

Application of the political question doctrine in the foreign affairs arena is illustrated by the various suits brought in United States courts challenging the undeclared Vietnam War. The Constitution expressly provides that Congress has the sole power to declare war, and the power to raise and support the armed forces. ${ }^{213}$ Despite these constitutional provisions, numerous wars were fought by the United States after World War II without an express declaration of war by Congress, including the Vietnam War. As Presidents committed more and more troops to the Vietnam conflict and expanded the scope of the war, several cases were litigated challenging United States involvement on the grounds that Congress never officially declared war against North Vietnam, and therefore, the war was unconstitutional.

In one of the first such cases, Atlee $v$. Laird, ${ }^{214}$ the plaintiffs argued that the United States involvement in Vietnam constituted a "war," and that because Congress had not declared a war, the President was acting unconstitutionally by keeping American forces in South Vietnam. The court dismissed the case, however, on the grounds that the complaint presented a non-justiciable political question. Questions of whether American participation in South-East Asia constituted a war, whether Congress had taken sufficient action to authorize the war, and whether the President was justified in maintaining troops in Vietnam, in the court's opinion, presented the kinds of problems characteristic of political questions, such as the unavailability of judicially manageable standards, the commitment of the issues to the coordinate branches of government, and the lack of available information. As a matter of judicial prudence, the court felt that the matter was better left to the political branches to resolve. If the President was acting beyond his authority, it was Congress's responsibility to take appropriate action.

In subsequent cases, the courts moved away from the absolutist approach in Atlee v. Laird, and ruled that some Congressional involvement is required to authorize a war. For example, in Orlando $v$. Laird, ${ }^{215}$ the Second Circuit ruled that there must be some mutual participation between Congress and the President sufficient to ratify or authorize military activities. The Gulf of Tonkin Resolution, in

213. U.S. Const. art. I, sec. 8 , cls. 11, 12-14.

214. 347 F. Supp. 689 (E.D. Pa. 1972), aff d sub nom. Atlee v. Richardson, 411 U.S. 911 (1973).

215. 443 F.2d 1039 (2d Cir.), cert. denied, 404 U.S. 869 (1971). 
combination with draft extensions and budget appropriations, provided evidence supporting a conclusion that mutual participation by the Congress existed authorizing military activities. However, a political question still remained.

[T] gress has chosen to ratify and approve the protracted military operations in Southeast Asia is a political question. The form which congressional authorization should take is one of policy, committed to the discretion of the Congress and outside the power and competency of the judiciary, because there are no intelligible and objectively manageable standards by which to judge such actions. ${ }^{216}$

The courts in other cases came to the same conclusion. Even in Mitchell $v$. Laird, ${ }^{217}$ where the District of Columbia Circuit Court of Appeals found that defense appropriations and draft extensions did not constitute valid assent to the Vietnam War by Congress, the judges declined to rule for the plaintiffs because review of the President's decision to continue prosecution of the war presented a political question.

In Holtzman $v$. Schlesinger, ${ }^{218}$ the plaintiffs argued that the bombing of Cambodia and elsewhere in Indochina in 1973 constituted a "basic change in the war" such that an express declaration of war was required. The Second Circuit, reversing a lower district court decision that ruled in favor of the plaintiffs, dismissed the complaint on the grounds that whether or not there was a basic change in the war also presented a political question.

Throughout the Vietnam War litigation, the Supreme Court avoided ruling on the issues raised. The Supreme Court denied certiorari in case after case, often over the strong dissent of Justice Powell and others. Consequently, the Supreme Court never ruled conclusively on the constitutionality of the Vietnam War, although there is evidence that at least one justice, Justice Stewart, believed the United States involvement in Vietnam was unconstitutional. ${ }^{219} \mathrm{Nev}$ ertheless, the political question doctrine is still invoked by courts in cases challenging the Presidential introduction of troops into foreign conflicts. For example, in Crockett $v$. Reagan, ${ }^{220}$ twenty-nine Members of Congress brought suit challenging President Reagan's introduction of American military advisors into El Salvador as a violation of the War Powers Resolution. The court dismissed the case as a nonjusticiable political question on the grounds that the fact-finding re-

216. Id. at 1043-44.

217. 488 F.2d 611 (D.C. Cir. 1973).

218. 484 F.2d 1307 (2d Cir. 1973), cert. denied, 416 U.S. 936 (1974).

219. See Yoder, "A Judge and the War," Washington Post, Dec. 10, 1985, at A21.

220. 558 F. Supp. 893 (D.D.C. 1982), affd, 720 F.2d 1355 (D.C.Cir. 1983), cert. denied, 467 U.S. 1251 (1984). 
quired to determine whether United States forces had been introduced into hostilities was beyond the ability of the court.

While questions of whether Congress has authorized military activities and the level of hostilities faced by United States forces are non-justiciable, not all issues relating to the conduct of hostilities are subject to the political question doctrine. The courts will exercise their jurisdiction if the parties present claims that fall within the court's traditional expertise. For example, in Ramirez de Arellano $v$. Weinberger, ${ }^{221}$ an American citizen living in Honduras, challenged the United States Government's use of his property in Honduras for the military training of personnel from the army of El Salvador. The district court dismissed the case as a non-justiciable political question. The District of Columbia Circuit Court of Appeals reversed, however. The court found that the plaintiffs claims fell within the normal competence of the courts, in particular its general expertise in the resolution of property claims. In the court's view, none of the prudential considerations that bar a claim under the political questions doctrine were present in this case. Reinstating the cause of action, the court noted that the political question doctrine is "a tempting refuge from the adjudication of difficult constitutional claims," and warned against its "indiscriminate and overbroad application to claims properly before the federal courts."222

\section{The Role of the Citizen (Individuals and NGOs) in Foreign AfFairs}

The Preamble of the United States Constitution begins with the words "We the People of the United States ...." This reference to "the people" highlights the central role played by individual human beings in the American constitutional system. Not only does the Constitution protect the rights of individuals against the government, but it is through the civic activities of citizens, both in their individual capacity and as members of groups, that the constitutional system of the United States comes alive. The health of the democracy and the responsiveness of the government to the will of the people depend directly on the active participation of the American citizen.

The central role of the individual in the American constitutional system is in no way diminished in the foreign affairs arena. Indeed, with the growing interdependence of all the nations of the world, foreign affairs are simply too important to be left to a few people. Through a variety of modalities, the individual citizen has the opportunity to influence the contours of American foreign policy, and contribute to the United States' role in the family of nations.

221. 745 F.2d 1500 (D.C. Cir. 1984).

222. Id. at 1514 . 
Obviously, the most direct impact a citizen has on the United States foreign policy is through the electoral process. Individuals, working individually, in political parties, and through nongovernmental organizations (NGOs) devoted to specific issues areas, work to get candidates on the ballot, support their campaigns with time and money, and ultimately go to the polls to elect the representatives they think best represent their interests. Exercising the right to vote, citizens have the most direct influence on who their Senators, Representatives, Presidents and Vice-Presidents will be, and hence, what kinds of international policies will be pursued by the government.

But citizen input into American foreign policy is not limited only to elections. Another significant modality for influencing American foreign policy is through the power of public opinion. Elected representatives, even if not immediately facing an up-coming election, are nevertheless sensitive to the demands and expectations of the general citizenry. Publicity and public pressure on any given issue will influence the decision makers responsible for developing and implementing American foreign policy. The experience during the Vietnam War provides a classic example of this process: growing discontent and protest over the conduct of what became an unpopular war was one of the factors that eventually forced the government to withdraw from the conflict. The general lesson of the war was that when the government in a democracy loses the support of the people, it will be very difficult to conduct a successful foreign policy.

Ultimately, not only do individual citizens exert an important influence on the United States government, but a successful foreign policy also depends on an active and concerned citizenry. The strength of the democratic system is that it provides a forum for the clash of competing values and ideas, and a mechanism for their resolution that does not require the resort to civil strife and insurrection. But if citizens are not involved in the democratic process, their interests are not adequately represented, and the government drifts away from the control of the people. When the government ceases to represent the values of the governed in its foreign policy, it is ultimately the citizen's responsibility, exercising their rights as citizens, to make the changes necessary to assure that their values are adequately reflected in the nation's policies.

Organically, the Constitution recognizes three branches of government as the decision making organs of the federal government. In reality, individuals are involved in all seven decision functions that characterize the process of authoritative decision making in the foreign affairs arena: intelligence, promoting, prescribing, invoking, applying, terminating, and appraising.

The intelligence function relates to the gathering, processing, and disseminating of information essential to decision making. Each 
branch of the federal government participates in the intelligence function regarding foreign affairs. The Central Intelligence Agency (CIA), the National Security Council, and the diplomatic corp provide information to the Executive, congressional investigators report to congressional committees, and the courts receive evidence about conditions abroad in appropriate cases. But the three branches do not have a monopoly on information or fact-finding. In an open, democratic society, individuals and groups are constantly involved in the process of collecting and reporting information. Individuals, working through NGOs, document human rights abuses around the world, monitor environmental conditions, collect economic indicators, and report on political, social and cultural development worldwide. The press, with individual reporters scattered around the globe, keep us supplied with current information about events taking place in distant places.

The promoting function is defined as the advocacy of general policies and urging proposals. The involvement of individuals and NGOs in the promotion of new prescriptions is a distinctive characteristic of a democratic form of government. Individuals contact their local representatives, making demands and pressing their ideas. NGOs send lobbyists to Washington to promote group interests. Both use the means of mass communication to build interest and support, mobilizing public opinion and pressuring politicians to achieve policy goals on matters of foreign aid, international trade, relations with foreign states, and international law-making. For example, after years of lobbying efforts by Amnesty International, International League for Human Rights, Lawyers Committee for Human Rights and other NGOs, the United States finally ratified the International Covenant on Civil and Political Rights. ${ }^{223}$ Next on the agenda is ratification or accession to other human rights treaties including the International Covenant on Economic, Social and Cultural Rights, ${ }^{224}$ the Convention on the Elimination of All Forms of Discrimination Against Women, ${ }^{225}$ and the International Convention on the Elimination of All Forms of Racial Discrimination. ${ }^{226}$

While the prescribing function, or the projecting of community policy through lawmaking, is constitutionally delegated to government officials, individuals also play an important role. For example,

223. International Covenant on Civil and Political Rights, Dec. 16, 1966, 999 U.N.T.S. 171 (entered into force March 23, 1976).

224. International Covenant on Economic, Social and Cultural Rights, Dec. 16, 1966, 993 U.N.T.S. 3 (entered into force Jan. 3, 1976).

225. Convention on the Elimination of All Forms of Discrimination Against Women, Dec. 18, 1979, U.N.G.A. Res. 34/180 (XXXIV), 34 U.N. GAOR Supp. (No. 46) 194, U.N. Doc. A/34/830 (1979), reprinted in 19 I.L.M. 33 (1980) (entered into force Sept. 3, 1981).

226. International Convention on the Elimination of All Forms of Racial Discrimination, Dec. 21, 1965, 660 U.N.T.S. 195 (entered into force Jan. 4, 1969). 
during negotiation by the Office of the United States Trade Representative over the North American Free Trade Agreement (NAFTA), NGOs were actively engaged in influencing and shaping provisions of the agreement relating to environmental and labor issues. The ultimate passage of NAFTA by the Congress reflected to some extent the perceptions of congressional members about the degree of support of the American people.

Individuals in the United States are particularly active in the invoking function - the provisional characterization of certain conduct in terms of conformity or deviation from community norms. America is an alert and litigious society. There is hardly a government action that does not go unchallenged in the courts, as illustrated by the variety and scope of cases in the foreign affairs field. Individuals are also active before executive and administrative agencies, invoking procedures and seeking remedies in such diverse areas as international trade, environmental issues, and immigration.

In terms of application, or the characterization and execution of prescriptions in concrete situations, this role is traditionally considered to be within the purview of the Executive, as the branch responsible for executing the laws of the United States, and the courts, as the branch responsible for applying laws to actual cases. While the final application of the law in any given case is subject to the discretion of the judge, individuals also participate in the process as amicus curiae, or "friend of the court." An amicus curiae is generally an individual attorney, private citizen, or representative of an NGO, invited to present information on questions of law relating to a case currently before the court. Through this process, individuals have had the opportunity to influence directly judicial deliberations. The Lawyers' Committee for International Human Rights, a New York based NGO, for example, has successfully used the amicus curiae procedure to secure the right of refugees and asylum seekers in the United States courts.

As in the promoting function, individuals and NGOs are also actively and continuously engaged in the termination function - the process of putting an end to an existing prescription - and the appraising function - the critical evaluation of community policies in terms of community goals. The First Amendment freedom of expression, one of the most cherished of the rights protected by the Constitution, is directly related to these functions; in the United States an individual is free to criticize the government, and to petition the government for a redress of grievances. One does not have to be an expert in order to participate in appraising United States foreign policy. Although the contribution of scholars, practitioners, and commentators is important, participation by ordinary individuals is a key as- 
pect of the democratic form of government, and a necessary component of its successful operation.

In conclusion, the conventional wisdom is that the power to conduct foreign affairs in the United States is exercised by a relatively few high government officials. In reality, individuals from all walks of life are constantly involved in the processes through which American foreign policy is formed - in an open, democratic society, anyone may make a contribution.

\section{Conclusion}

A critical appraisal of the constitutional system of the United States reveals a dynamic constitutive process of authoritative decision in which all participants in American society act to shape and share values, and establish the norms and laws that govern society. Through an on-going process of communication, practice, and decision, the demands and expectations of succeeding American generations are fulfilled, giving "life" to the ideals enshrined in a document drafted over two hundred years ago.

A core feature of this constitutional process is the commitment to the protection of fundamental freedoms and rights of individuals, as guaranteed by the dynamic Bill of Rights. In terms of prescription, the Bill of Rights gives special recognition and protection to the most highly cherished and deeply demanded rights by express and formal prescription in the constitutive document itself. In terms of invocation, individuals can challenge the deprivation of their individual rights and obtain remedies for their violation by invoking them before appropriate decision makers. In terms of application, special provisions are made for the application of intensely demanded human rights prescriptions against violators, whether within or without government. Finally, in terms of termination, the human rights protected by the Bill of Rights cannot be terminated except by extraordinary effort (such as by amendment to the Constitution) or in the same way in which they were created. ${ }^{227}$

The features that characterize the constitutive processes of the United States generally can also be observed in the conduct of American foreign affairs. The foreign affairs powers of the United States are vested in the federal government, and constitutional principles such as federalism, separation of powers, and checks and balances apply to the conduct of foreign affairs by the President and Congress. In addition, the limitations imposed by the Constitution, and in particular the Bill of Rights, also apply, qualifying the exercise of foreign affairs powers by government officials. But when viewed in the con-

227. For a more detailed description of the Bill of Rights in action, see generally Chen, supra n. 5. 
text of an expanded notion of foreign affairs, all the features of the constitutive process that govern domestic relations also affect American international relations. Even though foreign affairs are formally vested in the federal government, states, local governments, non-governmental organizations, and individuals all have a role in shaping and sharing in American foreign policy decisions.

Questions regarding formal structural theories of American government, such as the theory of separation of powers, are also increasingly difficult to resolve as the line between matters of international concern and domestic jurisdiction blurs. Formally, the President is the sole representative of the United States in foreign relations. But as domestic problems increasingly require regional or international cooperation for their resolution, Congress's role in the establishment of foreign affairs, particularly as the regulator of foreign commerce, becomes ever more relevant and important.

Ultimately, however, the constititutional system in the United States seeks to establish a rule of law wherein no person, whether common citizen or high government official, is above the law. The power dimension in the American system is tempered by and in tension with the human rights dimension; the protections of the Bill of Rights apply to the acts of government officials, whether acting in the domestic, or the international realm. International treaties and agreements, as a part of federal law, are part of the supreme law under the Constitution and binding not only on the federal government, ${ }^{228}$ but state and local governments as well.

The success of the constitutional system in the United States depends in large measure on a constitutional culture that helps it thrive. The constitutional experience is an on-going process of clarifying and securing common goals and interests. It is a practice where community members work together to shape and share important values. Without input from the citizens who make up American society, the constitutional system would soon become irrelevant, or worse. Through ongoing effort and struggle, Americans have kept their constitution "alive."

Another condition necessary for the successsful functioning of the American system is an independent judiciary. Since the days of Marbury v. Madison, the judiciary has served as a check on the power of the Executive and the Congress, often protecting minority interests from overreaching by the majority. Without a judiciary capable

228. What is less clear is the extent to which the rule of law prevents the President from violating customary international law, either to serve domestic needs or as an attempt to establish a new norm of customary law. See Fernandez-Roque v. Smith, 622 F. Supp. 887 (N.D. Ga. 1985), aff'd in relevant part sub nom. Garcia-Mir v. Meese, 788 F.2d 1446 (11th Cir.), cert. denied, 479 U.S. 889 (1986). See also Restatement, supra n. $77 \S 115$ Rep. Note 3; Agora, "May the President Violate Customary International Law," 80 Am. J. Int'l L. 913 (1986). 
of functioning independently from the other branches, and from politics in general, the advances in human rights for which the United States courts are known might not have been possible. To a large measure, the Court's prestige and expectations of authoritativeness derive from the perception that its decisions are generally based on principle, not political expediency.

A responsible press is also a necessary condition for a successful constitutional culture. In a system that depends on an informed electorate, citizens must have accurate and relevant information about the activities of their elected officials and the consequences and effectiveness of public policies adopted by the government. A press that reports only on the trivial, irrelevant, or exploitative does a disservice to the democracy in which it operates.

Finally, the American constitutional system is characterized by the vigorous role played by the individual. It is ultimately for the protection of the individual that the constitution was designed. And it is the responsibility of the individual to keep the system working. All members of American society have a role in the functioning of the American constitutive process, whether it be the reporter who collects the information regarding America's role in world affairs, the lobbyist who promotes a new approach to international environmental law, a lawyer who files a complaint to vindicate someone's human rights, or a private citizen who goes to the polls to elect a President. This is the essence of American constitutional culture and democracy in action. 
$-$ 